\title{
Style and substance: some metal figurines from south-west Britain
}

Article

Accepted Version

Durham, E. (2014) Style and substance: some metal figurines from south-west Britain. Britannia, 45. pp. 195-221. ISSN 1753-5352 doi: https://doi.org/10.1017/S0068113X14000270 Available at https://centaur.reading.ac.uk/39196/

It is advisable to refer to the publisher's version if you intend to cite from the work. See Guidance on citing.

To link to this article DOI: http://dx.doi.org/10.1017/S0068113X14000270

Publisher: Society for the Promotion of Roman Studies

All outputs in CentAUR are protected by Intellectual Property Rights law, including copyright law. Copyright and IPR is retained by the creators or other copyright holders. Terms and conditions for use of this material are defined in the End User Agreement.

\section{www.reading.ac.uk/centaur}

\section{CentAUR}

Central Archive at the University of Reading

Reading's research outputs online 


\title{
Author's Original Manuscript - Postprint
}

This is an Author's Accepted Manuscript of an article published as: Durham, E. (2014) 'Style and Substance: Some metal figurines from south-west Britain.' In Britannia, First View,

Published online 20 May 2014

Cambridge University Press, available online at:

http://journals.cambridge.org

\section{Style and Substance: Some Metal Figurines from South-West Britain}

\author{
by EMMA DURHAM
}

\begin{abstract}
A hoard found in Southbroom, Devizes in 1714 contained a group of copper-alloy figurines executed in both classical and local styles and depicting deities belonging to the GraecoRoman and Gallo-Roman pantheons. The deities in a local style appear to form part of a larger tradition of figurines, predominantly found in the South-West, which are characterised both by a similar artistic style and the use of Gallo-Roman symbolism and deities, such as the torc, ram-horned snake, carnivorous dog and Sucellus. The unique composition of the hoard in comparison with other hoards of similar date provides insights into the beliefs of Roman Britain.
\end{abstract}

\section{Keywords: dog, figurine, Gallo-Roman, religion, Southbroom, Sucellus}

A range of styles is seen among the metal figurines from Roman Britain including imported, highly classical pieces and figurines exhibiting various provincial features. Little thought has been given to the origins of these provincial figurines and once many were assumed to have been made in Gaul. ${ }^{1}$ However, the presence of figurines depicting a specifically RomanoBritish subject, such as the horse and rider figurines of eastern central England, imply that figurines were produced within Britain. There is little direct evidence for the production of figurines in Britain, but one example of a mould from Gestingthorpe (Essex), a site where bronze working was taking place in the third and fourth centuries, shows the stomach and thigh of a male and an ivy-leaf wreath, which indicates that this was probably Bacchus, or possibly a character associated with him. ${ }^{2}$ This paper examines the figurines exhibiting a specific range of stylistic traits which indicate the presence of a tradition in South-West England with a particular focus on the Southbroom hoard from Devizes (Wilts.). Some of the figurines in this hoard are in a naturalistic, Graeco-Roman style, while others are in a more native tradition exhibiting idiosyncratic attributes and employing an unusual and distinctive style which suggests that they were the product of the same workshop. Some of the attributes used, such as the ram-horned snake, are commonly associated with Gaul, while the presence of a particularly Gallo-Roman deity - Sucellus - might indicate a Gaulish origin for the pieces. However, a small number of other figurines, largely from sites in the region around Devizes, show similar stylistic traits to those of the Southbroom hoard and suggest that they were produced in this area. 
Also among the figurines from the Southbroom hoard is an unusual dog or wolf, which may depict a wolf deity. Once again the origins of this figure type may lie in Gaul, but two figurines from Llys Awel, north Wales, show a development of this theme which may be connected to the particularly British ritual associations with dogs. ${ }^{3}$

A close examination of both the stylistic and symbolic features of these figurines provides interesting insights into artistic and religious influences in early Roman Britain.

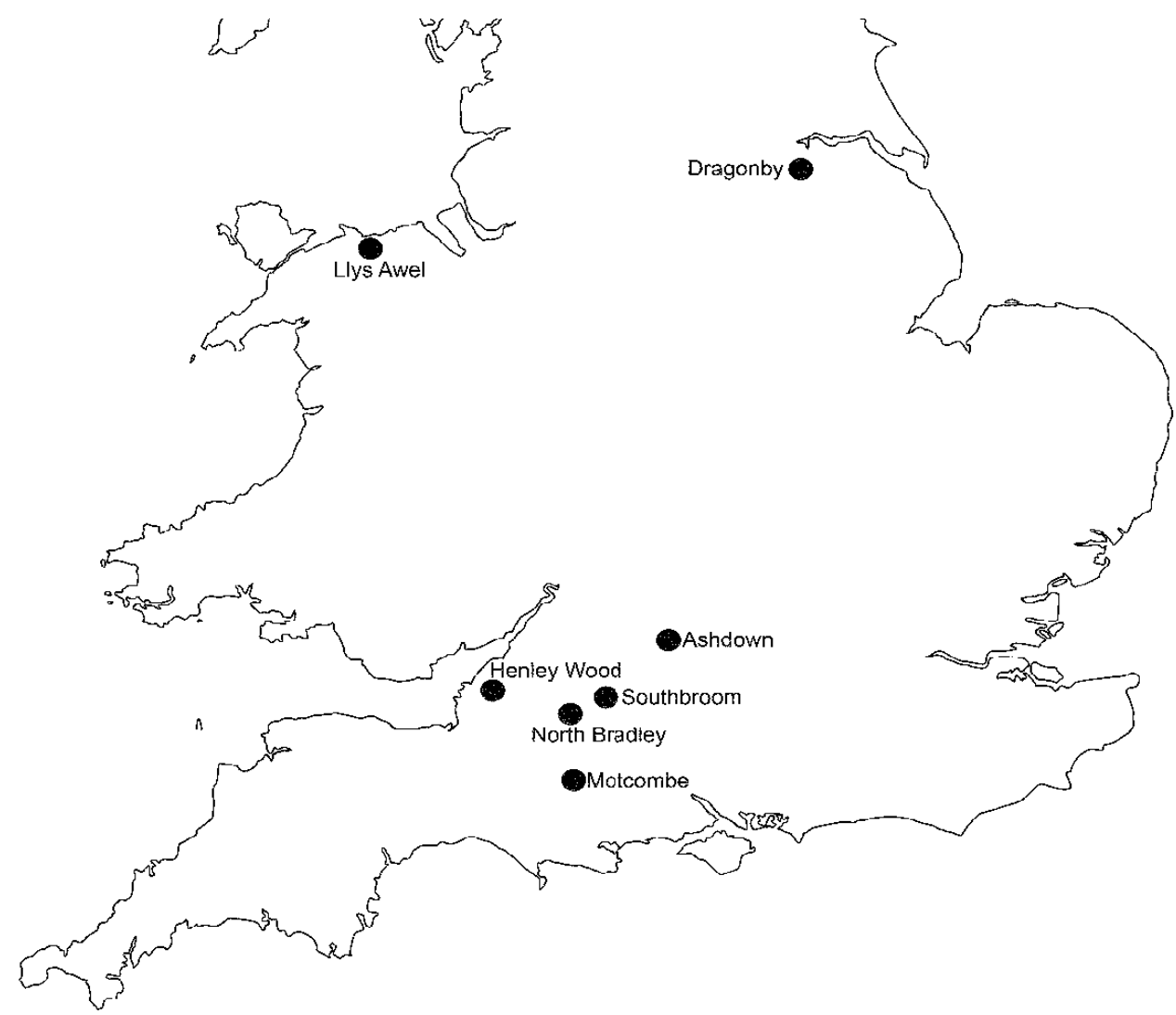

Fig. 1. Location of sites mentioned in the text

\section{THE COMPOSITION OF THE SOUTHBROOM HOARD}

The Southbroom hoard was discovered in 1714 just to the south of Devizes (FIG. 1). It consisted of a Roman pottery vessel containing coins, seventeen figurines (see Appendix), a steelyard weight in the form of a female bust and a discus from a picture lamp. Eight of the figurines are now in the British Museum while the remainder are lost, as are the weight and lamp. ${ }^{4}$ The only record of the missing objects is the original drawings, first published in 1717 and then again by Musgrave in 1719 (FIGS 2-3). The illustrations appear to be fairly accurate - both in direct comparison with the surviving figurines in the British Museum and as noted by Stukeley - although it is clear that a certain amount of interpretation has been undertaken as is often the case in antiquarian drawings. ${ }^{5}$ The illustration of the picture lamp shows that the discus was decorated with the figure of a curled sleeping dog. Roman picture lamps depicting curled dogs, sometimes with a puppy, occur in both bronze and clay and a firstcentury example is known from Colchester. ${ }^{6}$ 
Penates, apud Devifas, in BELGIO noftro Effoffi, Anno y 14
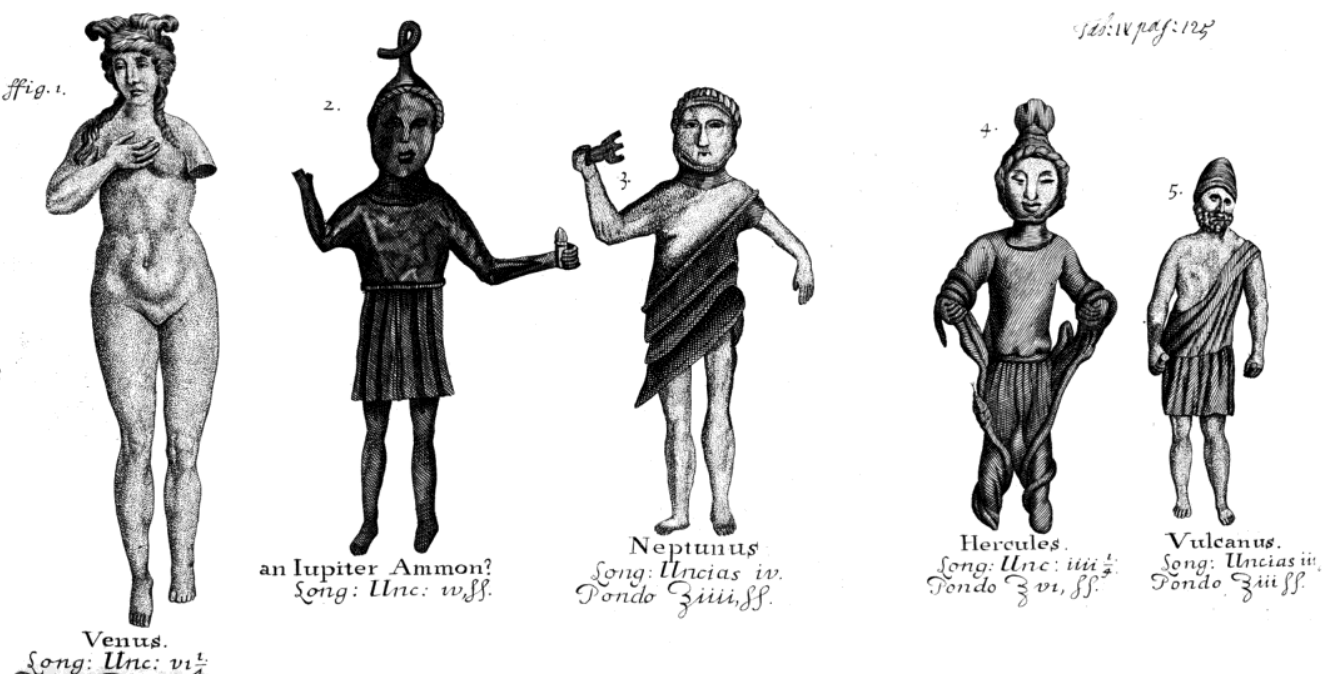

Pondo 3xi, fp.
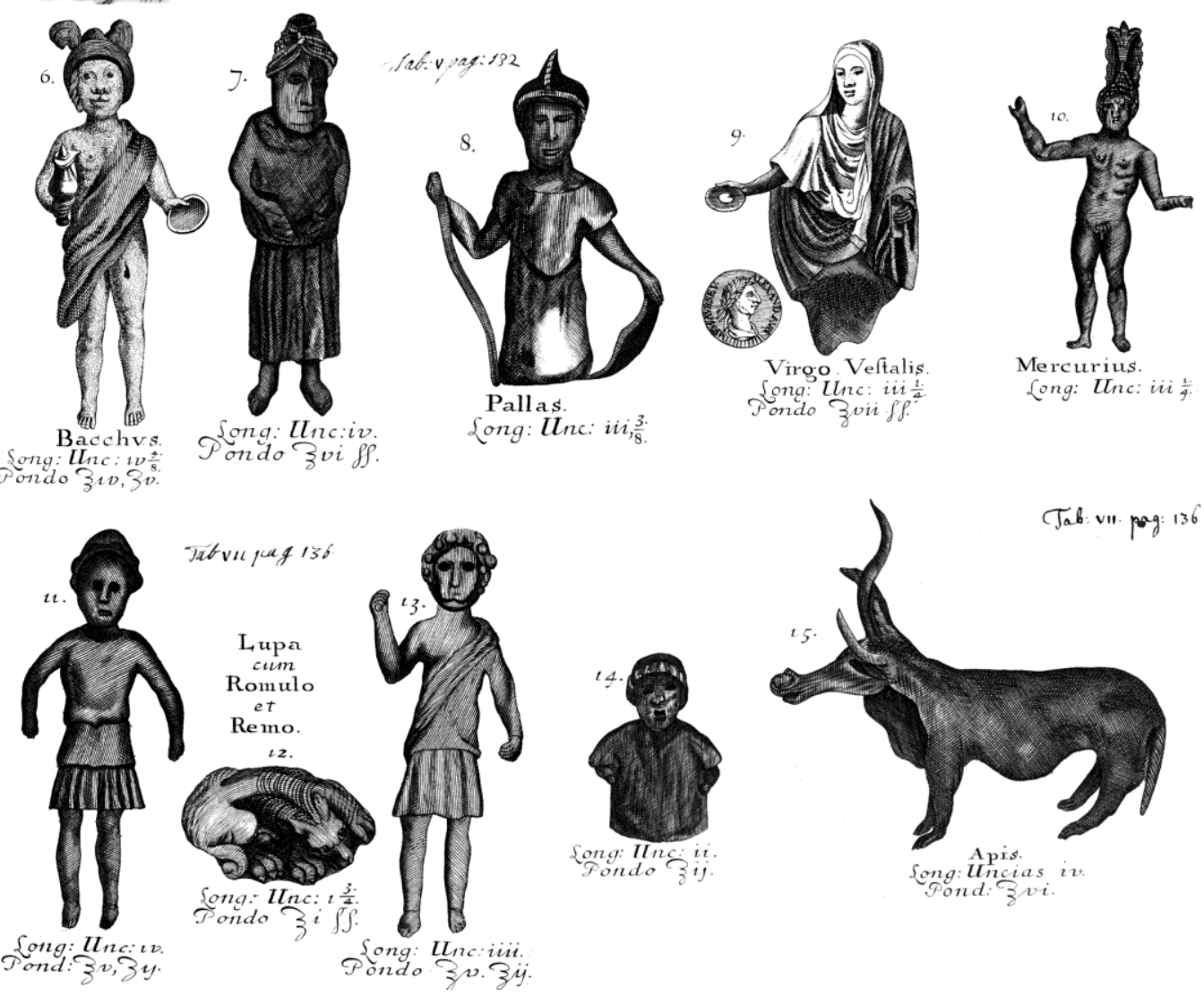

Fig. 2. The Southbroom hoard: Musgrave 1719, tables IV-VII. (Courtesy of the Bodleian Libraries, University of Oxford. Manuscript Gough Somerset 53) 


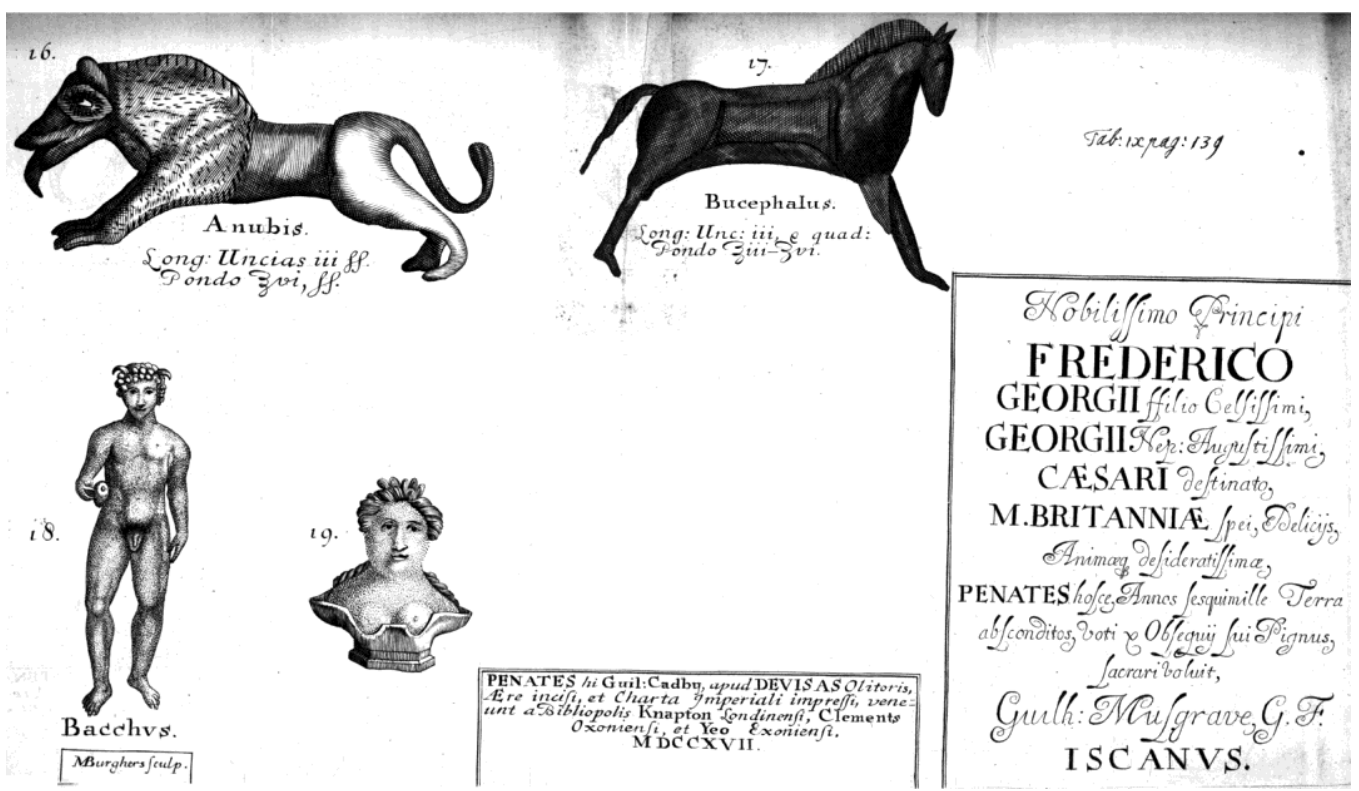

Fig. 3. The Southbroom hoard: Musgrave 1719, table IX. (Courtesy of the Bodleian Libraries, University of Oxford. Manuscript Gough Somerset 53)

The missing figurines from the hoard are Venus, Vulcan M5, Mars M10, Bacchus, Genius Paterfamilias, an unidentified deity, three-horned bull, dog or wolf and horse. All of the deities, except the unidentified piece, are typically classical examples of their type and are found on many sites both in Britain and on the Continent, while the three-horned bull and horse are less common. In fact, the three-horned bull is a Romano-Celtic mythological, perhaps divine, creature which originated in Gaul, and there are some 40 examples from that region, particularly in the valleys of the upper Rhône, Saône and Seine rivers in eastern Gaul, while there are seven from Britain. ${ }^{7}$ The dog or wolf figurine mentioned above is more unusual and will be discussed further below. A striking aspect of the Southbroom collection is the presence of both highly classical and provincial figures in the same hoard. As George Boon noted, the missing figurines could have been acquired by a collector who valued the classical pieces but rejected the provincial ones. ${ }^{8}$ However, while antiquaries may have considered the more native-looking pieces to be of inferior quality, they obviously were regarded highly enough in Roman times to take their place alongside classical figurines.

The rather unusual style and attributes of the provincial figurines has led to some confusion over their identities and, before beginning a detailed description of the stylistic attributes of the group as a whole, their identities are briefly reviewed (FIG. 4). Figurine M6 (FIG. 4b) is quite obviously Mercury, with the petasos (winged hat) and money purse which are seen with many Mercury figurines. The helmet and slightly clumsy depiction of a shield and spear identify figurine M8 as Minerva (FIG. 4g), while the tunic and pointed hat indicate that figurine M13 is Vulcan (FIG. 4d); both figurines are in stances that are fairly common for their type. ${ }^{9}$ Rather less common is the pose of the Mother Goddess (FIG. 4h), although a standing woman with her arms across her stomach is represented on other bronze figurines in Roman Britain. ${ }^{10}$ This posture is also shown on a stone figure from near the palace at Fishbourne (Sussex), ${ }^{11}$ which is made of Cotswold oolitic limestone, thus locating its place of origin near the figurines under discussion. Boon does not identify figurine M11 as any particular deity, while Miranda Aldhouse-Green suggests that it could be Hercules, ${ }^{12}$ but the posture, clothing and beard indicate that this is more likely to be Sucellus (FIG. 4c). Figurines from Augst, Switzerland and Chalon-sur-Sâone (Sâone-et-Loire), France are somewhat 

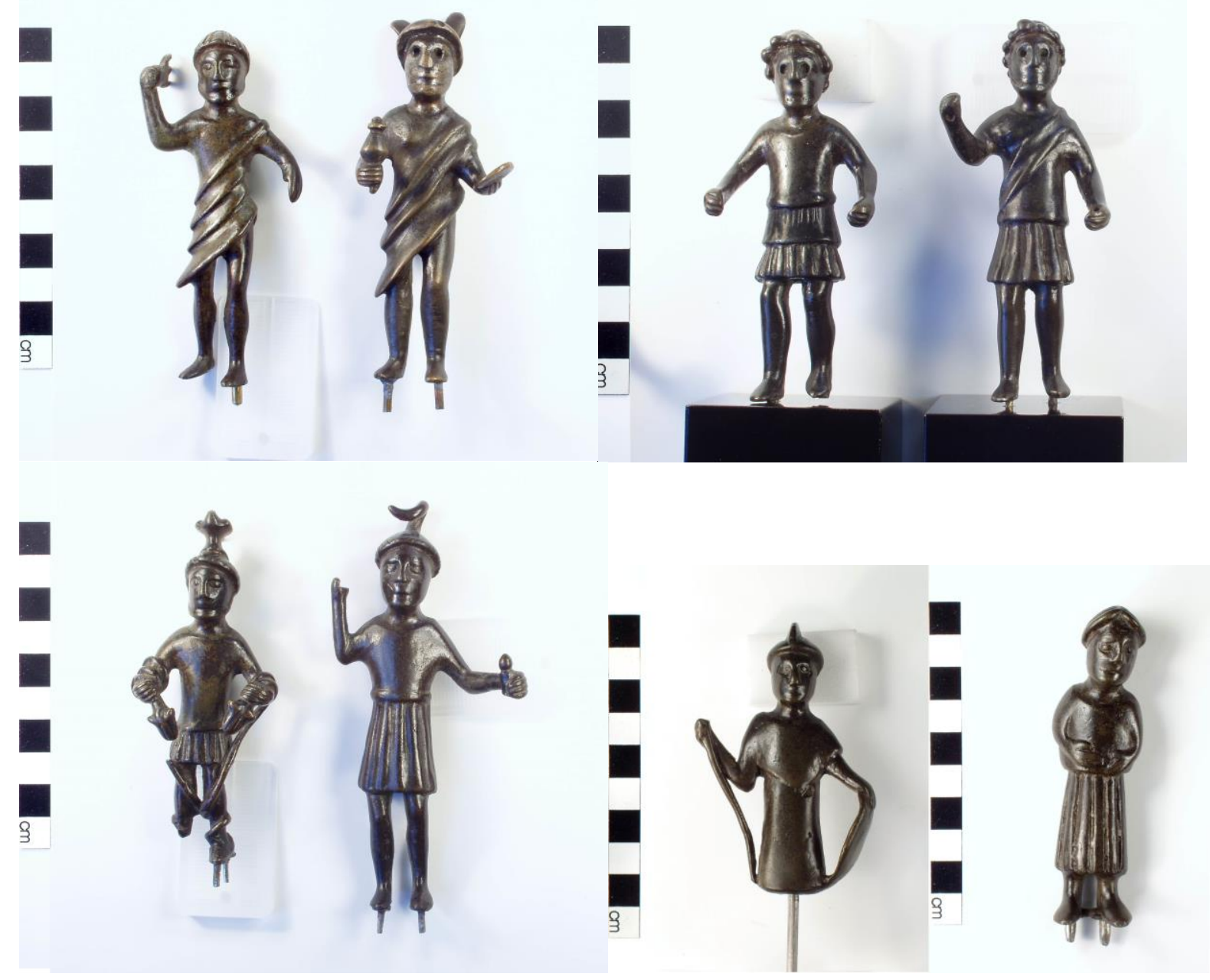

Fig. 4. Figurines from Southbroom: (a) Neptune; (b) Mercury; (c) Sucellus; (d) Vulcan M13; (e) Mars M4; (f) Mars M2; (g) Minerva; (h) Mother Goddess M7. (Reproduced by kind permission of the Trustees of the British Museum)

similar and both stand with the left hand palm up to hold the pot with which Sucellus is often depicted, while the Augst figurine also holds a fragment of an iron hammer in his right hand (FIG. 5). ${ }^{13}$ Unfortunately the attributes are missing from the clenched hands of the Southbroom Sucellus. Although Boon identified figurine M3 as Jupiter (FIG. 4a), it is interesting to note that Cunnington preferred Neptune. ${ }^{14}$ The figure is certainly holding a trident and although Neptune is not a particularly common subject for small bronzes, and this would be the only such figurine from Britain, he does appear in small numbers on the Continent. ${ }^{15}$ Two figurines, M2 and M4 (FIG. 4e and f), are particularly difficult to identify. Figurine M4 is called 'uncertain Celtic' by Boon, but he notes that Anne Ross identified it as Mars and this attribution was also accepted by Aldhouse-Green. ${ }^{16}$ The two attributes which led to the identification of this figure as Mars - the raven-topped helmet and the ram-horned snake which he holds in each hand - are more fully discussed below. It has also been suggested that figurine M2 could be Mars, although this identification is less certain. ${ }^{17}$ The stance and the helmet are typical of many Mars figurines, including the missing classical Mars M10 from the hoard. Although Mars M10 is nude, Mars M2 is clothed in a tunic with pleated skirt, a style of clothing which is seen on other Mars figurines. ${ }^{18}$ Finally, while 
figurine M14 is part of the stylistic group that forms the basis of this paper it is now missing, thus only the eighteenth-century illustration can be referred to and since only the head and upper torso remained it was not possible to identify which deity it depicted.

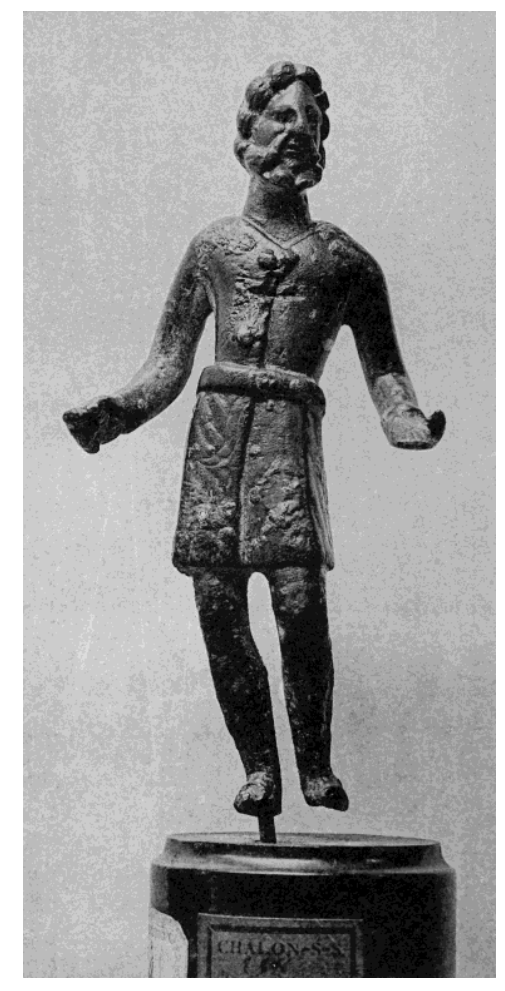

Fig. 5. Sucellus from Chalon-sur-Sâone, France. (Armand-Calliat 1937, pl. XIII)
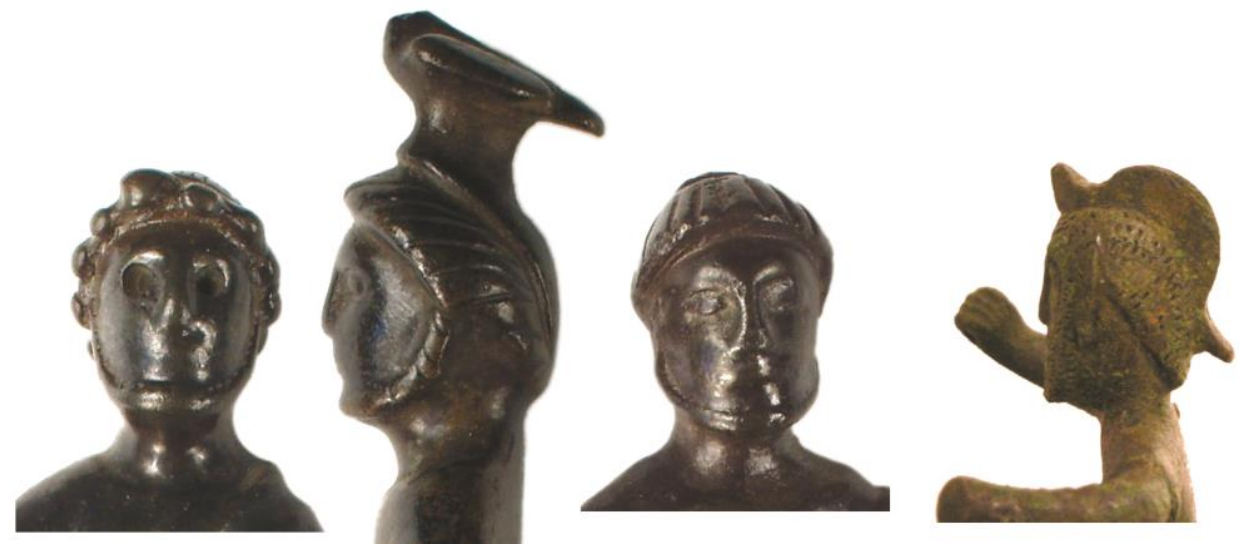

Fig. 6. The beards on: (a) Vulcan M13; (b) Mars M4; (c) Neptune (a-c Reproduced by kind permission of the Trustees of the British Museum) and (d) the Dragonby Mars. (Reproduced by kind permission of North Lincolnshire Museum Service)

\section{THE STYLE OF THE SOUTHBROOM FIGURINES}

An initial glance at the Southbroom figurines reveals certain immediate similarities between them: the overall plain, somewhat stylised execution; the stance with the legs parallel and knees slightly bent; small feet with no toes depicted; arms which are held out rather awkwardly from the body; the deeply socketed eyes of some pieces and the deep folds of the 
clothes. They are also all similar in size, ranging from c. 96-108 $\mathrm{mm}$ in height. There are, however, many other details which unite these pieces. While Mercury, Vulcan M13, Sucellus and the unidentified figurine have deeply socketed eyes, the Mother Goddess, Minerva, Mars M2, Mars M4 and Neptune have rather unusual moulded, almond-shaped eyes. All have broad wedge-shaped noses and small mouths which are formed by a short, straight moulding. Male deities Vulcan M13, Mars M4, and Neptune all have a raised moulding around the chin to represent the beard. The bristles are indicated by small dimples over the chin on Vulcan M13 and notches on Mars M4, while the beard on Neptune is not detailed (FIG. 6). Although Sucellus does not have this moulding, he does have dimples representing a beard on his chin.

Mercury, Minerva and Mars M2 all wear hats or helmets, the brims of which are moulded as a short ridge directly from the head with no indication of hair underneath. The remaining figurines have a similar moulding at the edge of their hair, which gives them the appearance of wearing a cap. The hair framing the faces of Vulcan M13 and Sucellus is in moulded knobs, while that of Mars M4 is an incised fringe which matches the decoration of his beard. The hair of the Mother Goddess is drawn to the back of her head in deep mouldings, with a flat, round bun at the back which is placed quite high on the head. The smooth top of the head on Sucellus suggests that he is wearing a simple cap. However, the Sucellus from Augst has hair that curls around his face to form a slight corona, while the back of the head is plain and the Southbroom Sucellus could be following that style. ${ }^{19}$ In addition, the figure from Chalon-sur-Sâone has rather knobbed curls around his face and a belted waist (FIG. 5), both similar attributes to those on the Southbroom figurine. ${ }^{20}$ Mars M4 wears a headdress or helmet depicted by a moulded strip from the top of the head to the nape of the neck, on top of which is a pedestal mounted by a bird, of which the head is missing. An actual helmet surmounted by a bird comes from a wealthy grave in a cemetery at Çiumeşti, Romania which was dated c. 240-130 B.C., although the helmet itself is of slightly earlier date. $^{21}$ Raven-topped helmets also appear on a stone pillar from the Mavilly (Côte-d'Or) shrine and birds of prey, possibly ravens, are depicted on the silver Gundestrup cauldron from Denmark. ${ }^{22}$ Two altars from Kings Stanley (Glos.) show Mars with a spear, shield and sword and a helmet which Ross suggests is topped by a raven, but others believe it is a plume and this does seem more likely. ${ }^{23}$ Apart from the martial association of the warrior's helmet, the raven in the Gallo-Roman world is associated with Mars the healer and is shown with a priest on the Mavilly relief. Finally, the raven is also depicted on a relief showing three genii cucullati and a fourth male figure from Lower Slaughter (Glos.). ${ }^{24}$ It would, therefore, appear that the raven was associated with various deities, including Mars, in Roman Britain if not before. The importance of the raven in the ritual life of Iron Age and Roman Britain is further evidenced by the inclusion of raven bones in deliberately placed deposits at a number of sites during those periods. ${ }^{25}$

The clothing worn by the various figurines in the group also exhibits stylistic patterns. Mercury and Neptune both wear drapery which extends in angular folds from the left shoulder to the right knee. The drapery finishes in an unusual position very high on the left hip, and in Mercury's case he exposes his left buttock (FIG. 7a). The Mother Goddess, Mars M2, Mars M4 and Sucellus all wear a plain tunic above a pleated skirt. The skirt pleats are shown as long, straight mouldings with no indication of movement either in the clothing or the body underneath. The use of deep moulding for pleats can be seen on many other provincial figurines and the use of this patterning, especially for drapery and hair, is a characteristic of Romano-British stone sculpture. ${ }^{26}$ All of the male skirts finish above the knee, while that of the Mother Goddess is rather more modest and extends to mid-calf length. Such a long skirt is also seen on the stone figure from Fishbourne. ${ }^{27}$ The plain upper garment worn by Sucellus unusually opens at the back and his skirt has an overfold decorated with 
short vertical incisions along the upper edge (FIG. 7b). Many other depictions of Sucellus show him wearing a simple jacket which is closed at the front by a belt, sometimes with a thick fold of fabric over the belt. ${ }^{28}$ Boon suggested that the jacket might represent a protective leather garment worn by an artisan, an item which would be appropriate for the hammer god. ${ }^{29}$ Vulcan M13 wears the attire seen on many other figures of this type: a pleated skirt, topped with a tunic which is fastened on his left shoulder, leaving the right shoulder uncovered. The unidentified figurine also wears a simple tunic on his upper body, but his lower body is missing so it is not possible to say whether he wore a pleated skirt. Minerva appears to be wearing a plain tunic which extends to near her knees (FIG. 4g). The lower part of the figurine is missing, but there is no indication of a pleated skirt. She also wears what appears to be a short cloak across her shoulders, which narrows to its lowest point in the midchest and back. Perhaps this was meant to represent the aegis often worn by Minerva.

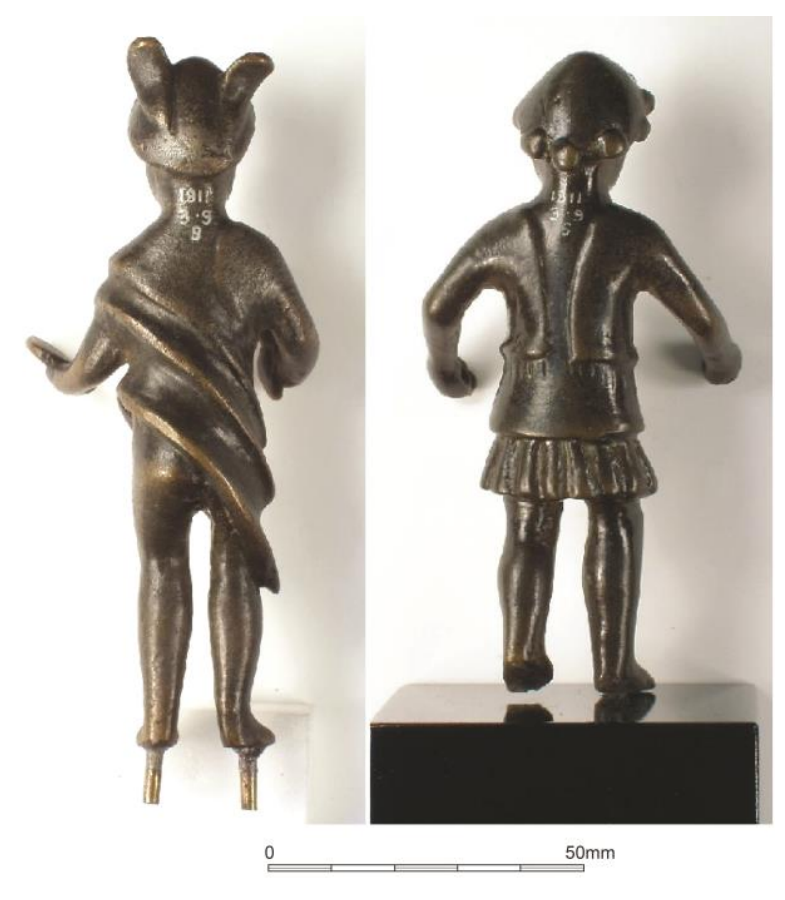

Fig. 7. The rear of (a) Mercury and (b) Sucellus. (Reproduced by kind permission of the Trustees of the British Museum)

All of the figurines hold, or would have held, attributes, except for the Mother Goddess whose hands are placed on her belly (FIG. 4h). The hands are all simple shapes, resembling mittens when extended or sockets when curled, usually with grooves indicating fingers. The lengths of the arms are not always anatomically correct; for instance the upper arms of Minerva and Mars M2 are too short. While some of the figurines are missing their attributes, others retain theirs. Mercury, as usual, has his purse, but it sits on top of his fist, and in his left hand instead of a caduceus he holds a patera (FIG. 4b). Although not a common attribute of Mercury, the patera is occasionally associated with him and two other examples are known from London and the Isle of Wight. ${ }^{30}$ Mercury is usually depicted holding his purse in one of two ways: on top of his palm or clutched with the bag hanging below the fist. The small pointed knob on top of Mercury's purse, as seen here, is often found at the base of hanging purses, while sometimes a flat knob is depicted at the top of the purse held on the 
palm. ${ }^{31}$ Of particular relevance here is a Mercury from Orbe (Vaud), Switzerland which shows Mercury with his hand clasped around the neck of the purse in the same manner as the Southbroom figure, but although the same shape the purse hangs below the fist. ${ }^{32}$ Thus it might be that the craftsman was familiar with both styles of purse, but slightly misinterpreted them here. However, Henig has also suggested that this is not a purse at all but a rattle, citing that from the Felmingham hoard. ${ }^{33}$ While an interesting idea and one that wouldn't be completely out of place in the rather eclectic mix of attributes present in the Southbroom group, it seems more likely that the object is in fact a purse.

Attributes are often used to identify figurines, but they do not always help with the Southbroom figurines owing to the use of unusual objects or the way in which the attributes are depicted. The ram-horned snakes of Mars M4 are not seen accompanying any other figurines in Britain (FIG. 4e), although this creature is associated with both Mars and Mercury in Gaul. ${ }^{34}$ Depictions of ram-horned snakes do occur in Britain, such as the two forming the legs of the god Cernunnos on a stone plaque from Cirencester and the snake that winds its way around an altar from Lypiatt Park (Glos). ${ }^{35}$ It is interesting to note that the two attributes of Mars M4 - the raven-topped helmet and the ram-horned snakes - are also both found on a pillar at the Mavilly shrine in France. ${ }^{36}$ Finally, Mars M2 holds an unidentified object in his left hand, a small cylinder with a cone-shaped top (FIG. 4f), but while his right arm is raised to hold an attribute, such as a spear, the hand is missing. The figure also wears a curious cap with a long curling tip which is perhaps meant to be a crested helmet, yet it in no way resembles the helmet worn by Minerva. Although the tip could simply be a casting sprue which was not removed, the helmet does appear to have been pointed or crested.

This examination of the Southbroom figurines shows that, although broadly united in a similar style, each of the figurines has unique details which not only make it stand out in this group, but also more generally from all others in Britain. They include elements which are classical, although individual, in style such as the purse and patera of Mercury or the style of the hair with the high bun of the Mother Goddess. However, a more Romano-Celtic style is seen in the raven-topped helmet and ram-horned snakes of Mars M4 or the jacket that fastens at the back of Sucellus. Although both of these figurines are unparalleled elsewhere in Britain, it is worthwhile considering whether there are any other figurines in Britain which exhibit a similar range of features to the Southbroom figures and which may, therefore, have been produced in the same workshop.

\section{OTHER FIGURINES IN THE SOUTHBROOM STYLE}

The first figurine to be considered is a Vulcan found by a metal detectorist in North Bradley (Wilts.) (FIG. 8a). ${ }^{37}$ This figure is rather stockier than the figurines in the Southbroom hoard, but does share some similarities with them, including the position and style of the legs, the straight pleats of the skirt and the awkward depiction of the arms with simple socketed hands. The use of a raised moulding to depict the beard is perhaps more significant, since this is not a feature commonly seen elsewhere in Britain other than on the Southbroom figurines. The bristles and hair underneath the pileus of the North Bradley Vulcan are depicted by short sshaped grooves. However, unlike the Southbroom figurines, the pleats of his skirt are decorated with horizontal hatching at the front and his eyes and mouth are more clearly defined. Henig notes the similarities between this figurine and those in the Southbroom hoard, but also points out that the depiction of the beard is similar to that on a Mars from Dragonby (FIG. 6d). ${ }^{38}$ The Dragonby Mars also has a small slit mouth, wedge-shaped nose and almond-shaped raised eyes. He has a full beard which leaves only a small part of the face uncovered and the hair of his beard and on his head is depicted by short, deep stab marks (FIG. 8b). The Dragonby figurine, like the North Bradley Vulcan, is quite stocky, and like the 
Southbroom figurines has a rather thin and flat profile (see FIG. 8c). The stylised depiction of his helmet is not unlike that seen on the Minerva or Mars M4 from Southbroom and like Mars M4 there is a narrow strip down the centre of the head. The Dragonby helmet has a narrow pointed ridge at the front and back and a deep groove along its length indicates the crest. Henig also highlights the belt worn by this figurine, but the belt on the North Bradley Vulcan is less obvious. In fact, all of the Southbroom figurines have a well-defined fold in the fabric between the tunic and skirt, and on two figures (Sucellus and Mars M2) the fold does appear rather like a belt.
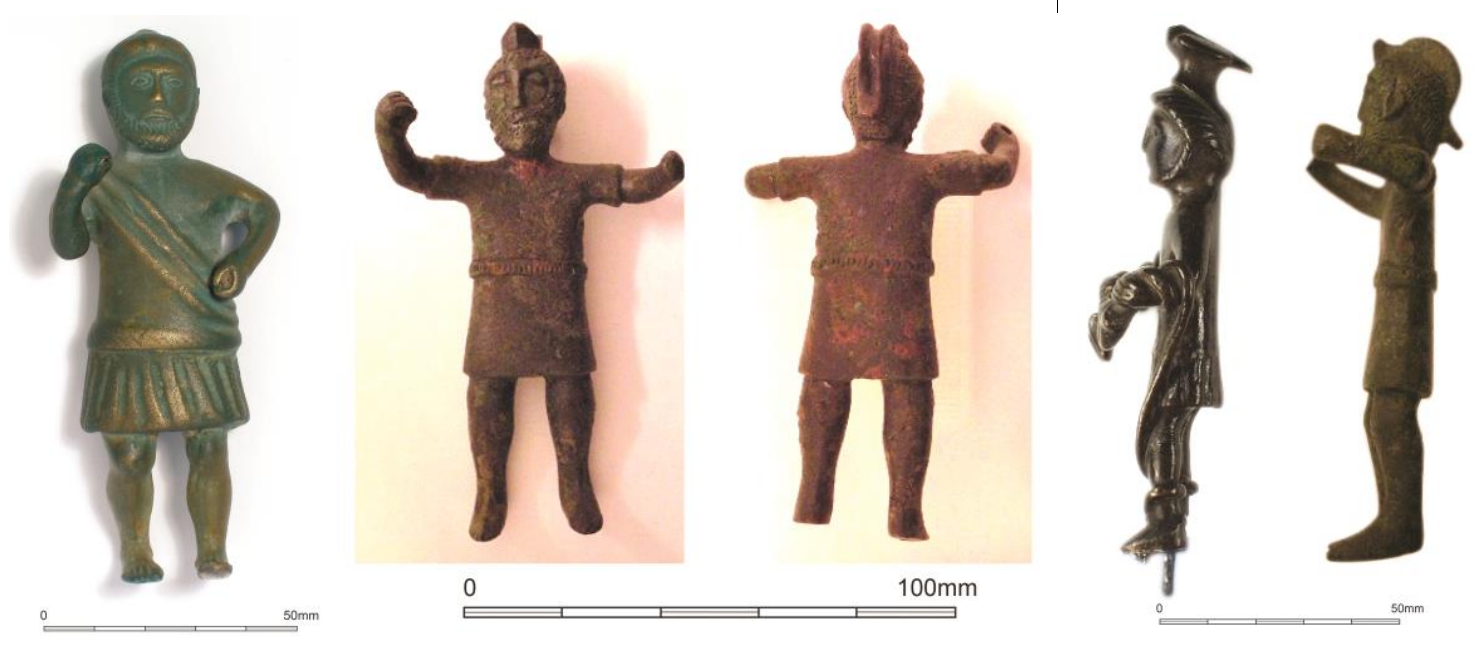

Fig. 8. (a) Vulcan from North Bradley (Wilts.) (Reproduced courtesy of Wiltshire Museum, Devizes); (b) Mars from Dragonby (North Lincs.) (Reproduced courtesy of North

Lincolnshire Museum Service); (c) Profiles of Mars figurines from Southbroom (M4) and Dragonby.

Two other figurines from the South-West also show affinities to the Southbroom pieces: a Mother Goddess from Henley Wood temple (Somerset) and a boar from Motcombe (Dorset). The Mother Goddess is a highly stylised figure depicting a nude standing woman with pendulous breasts (FIG. 9a). She stands with her legs together and they are defined by a vertical depression on the front and the back of the piece. Her arms are at her side with the hands clasped across her belly, thus in the same stance as the Mother Goddess from Southbroom. While the Southbroom Mother Goddess has her hair drawn back into a bun, the Henley Wood Goddess has a plaited band around her head. The latter's face is extremely worn, the nose and mouth are just visible, and the only real remaining features are her deeply socketed eyes, the left one of which still contains traces of fill. ${ }^{39}$ Around her neck she wears a rilled torc and it is this last detail in particular that links the Mother Goddess with the boar, or pig, from Motcombe.

The Motcombe boar is similarly stylised, with a rather cylindrical body which tapers slightly towards the neck (FIG. 9b). The face has a long, slightly tapering snout, and between the ears, now broken, are three grooves which Henig interprets as tufts of hair. ${ }^{40}$ Like the Henley Wood Mother Goddess this boar has deeply socketed eyes which may have held insets and around the neck he wears a decorated torc. Torcs are not often seen on metal figurines in Britain, and while there are two examples, both of Mercury, with a separately 


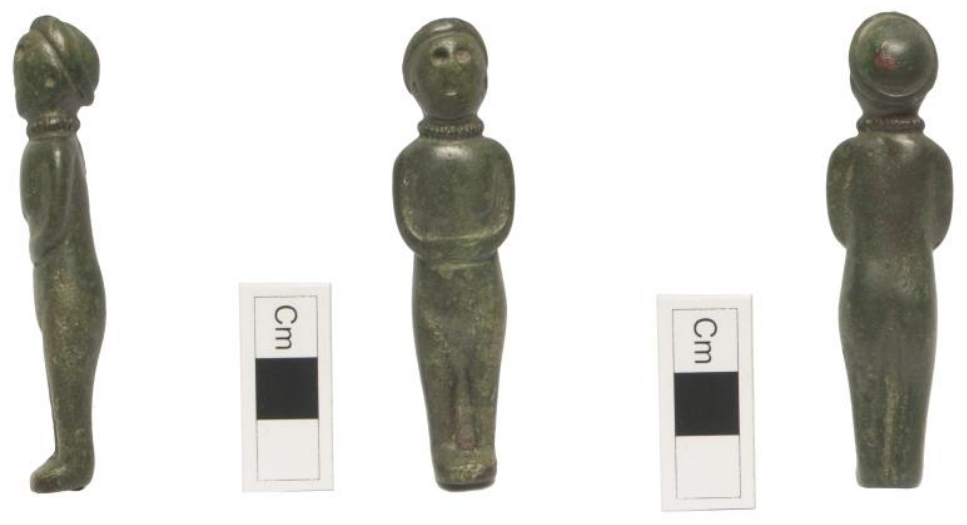

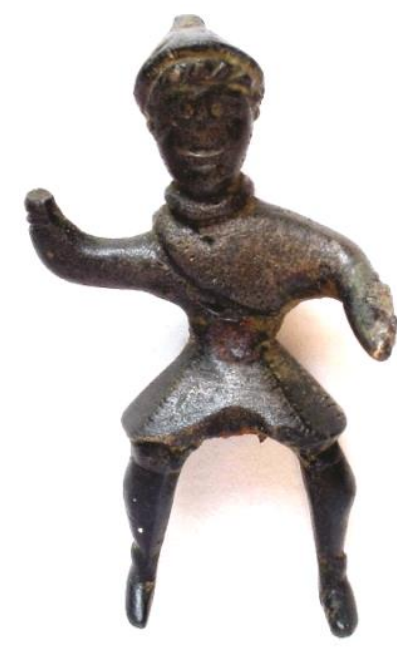

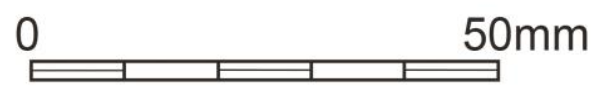

Fig. 9. (a) Mother Goddess from Henley Wood Temple (@) 2013 North Somerset Council and Somerset County Council Heritage Service); (b) Boar from Motcombe (Reproduced courtesy of Dorset County Museum); (c) Rider from Ashdown (Oxon.). (Reproduced by kind permission of the Trustees of the British Museum)

cast silver or gold torc, ${ }^{41}$ only one other figurine, a rider from Ashdown (Oxon.), has an integrated torc around the neck (FIG. 9c). ${ }^{42}$ There are also stone images of figures wearing torcs in Britain, such as that from Wellow (Somerset) which depicts a woman dressed in a long pleated tunic, much like that seen on the Southbroom Mother Goddess. ${ }^{43}$ The Ashdown rider is another stylised figurine which exhibits a similar style to that of the Southbroom figurines. In addition to the torc, he has close-set socketed eyes and a rather flat, almost featureless face in which the slit mouth is just visible; similar to the features also seen on the Henley Wood Mother Goddess. Like the helmet-wearing Southbroom figurines, the rider has a moulded helmet, with a brim forming a ridge around the head, but unlike the Southbroom figurines, he does have hair showing on his forehead. The helmet also has a crest, which is in the form of a narrow ridge along the back of the head, much like those seen on the Dragonby Mars and the raven-topped helmet of Mars M4. The clothing is very simply depicted, and does not have any deep folds or pleats, but the cloak is shown by a deep moulding, an effect 
common to the group as a whole and in particular to that on the Southbroom Minerva. The edge of the cloak is decorated with short notches, and similar nicks also decorate the facets of the tunic along the top of the thigh from waist to knee.

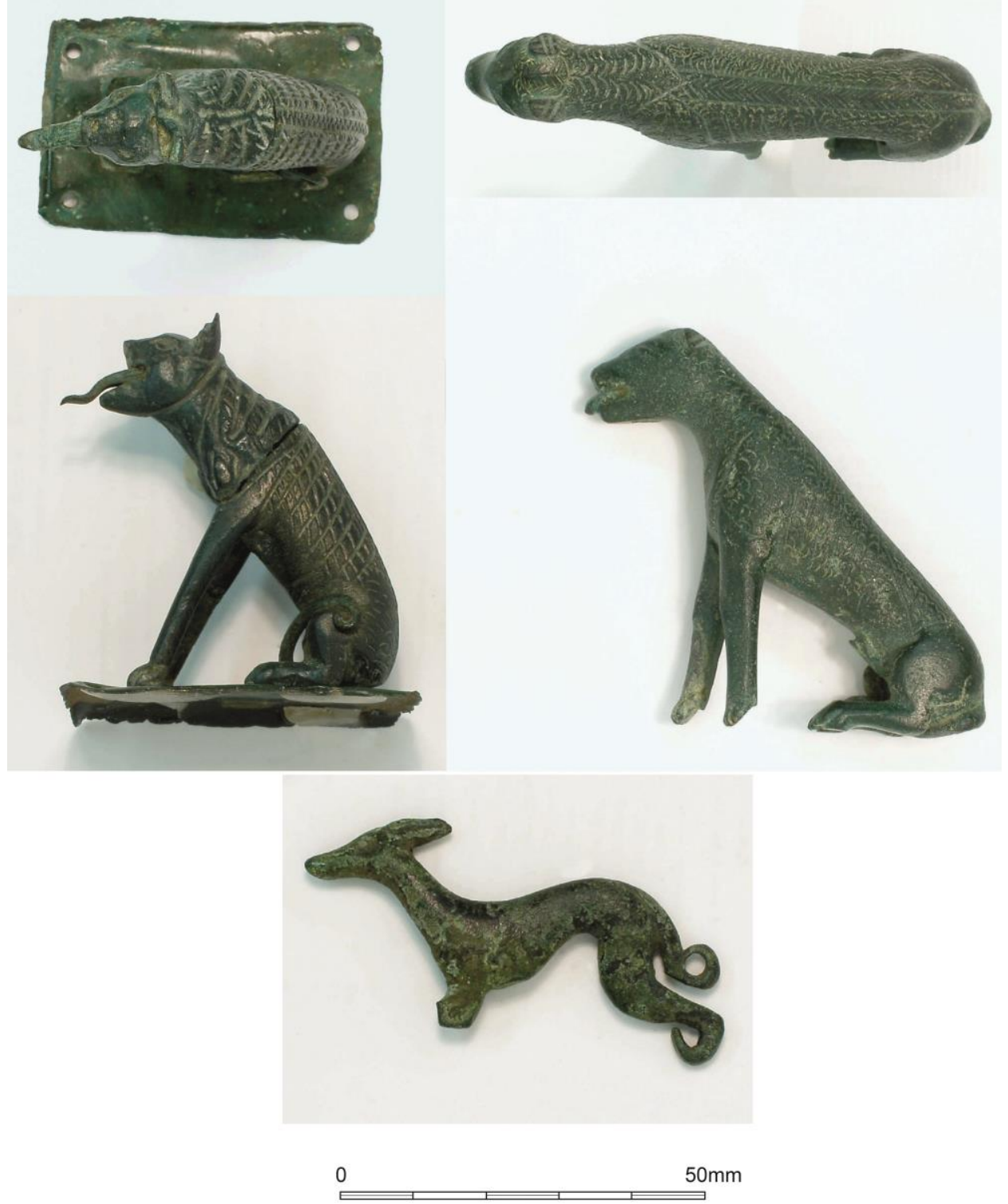

Fig.10. Dogs from Llys Awel, Conwy. (Reproduced with the kind permission of Amgueddfa Cymru - National Museum Wales)

\section{THE 'DOG MONSTER'}

Another small group of figurines examined here is that of the 'dog monster', canines with fierce features and long protruding tongues. One of the missing figurines from the Southbroom hoard was published as Anubis by Boon, ${ }^{44}$ but is now thought more likely to be another form of dog-like creature. The illustration published by Musgrave shows a powerful standing creature with protruding tongue, a mane from the back of his head to shoulders and rough bristled coat across the forelegs, neck and shoulders (FIG. 3 , no.16). ${ }^{45}$ 
The other examples in this group are all seated and include two figurines from Llys Awel (Conwy). ${ }^{46}$ These two creatures have open mouths from which protrude tongues, one of which is particularly long and wavy (FIG. 10). Their bodies are decorated with an incised pattern of cross-hatching and they have a dorsal ridge worked with a herringbone pattern. Their maleness is also emphasised in the depiction of the genitals. Other objects found with these dogs are another highly stylised dog in La Tène style, a Mercury figurine and three plaques, two of which also depict dogs.
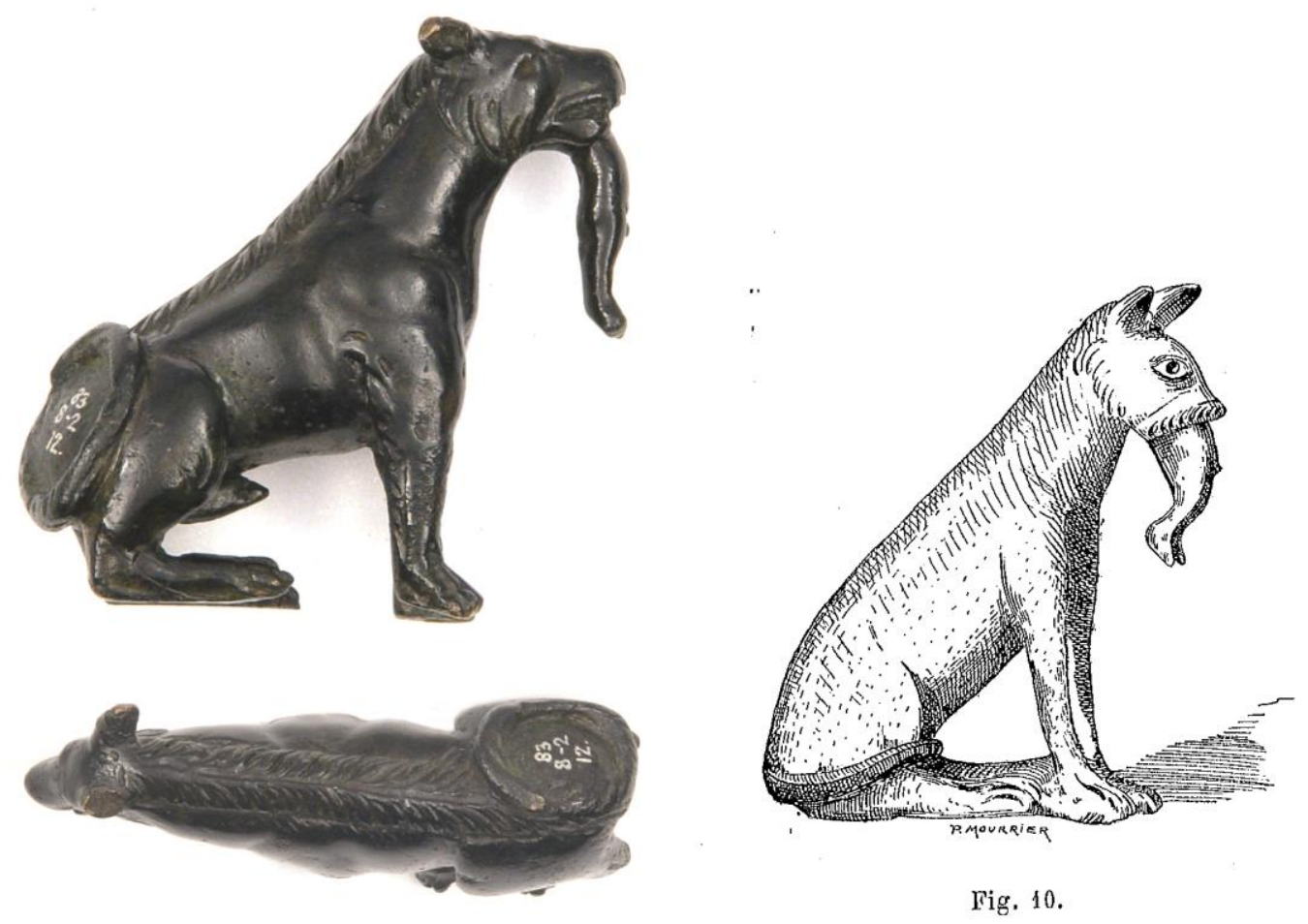

Fig. 11. (a) The wolf-god from Woodeaton (Oxon.). Scale 1:1 (CTrustees of the British Museum); (b) The carnivore from Fouqueure, France. (Chauvet 1901, fig. 10)

Another dog with a dorsal ridge, probably from the shrine at Woodeaton (Oxon.), has been described as a wolf-god (FIG. 11a). ${ }^{47}$ This muscular beast has a small human figure protruding feet first from its mouth, rather like the tongues on the Llys Awel dogs, and a patterned mane down its back. Depictions of the androphagous carnivore are found most often in north-eastern Gaul and apart from wolves or dogs can be lions, Cerberus, sphinxes, griffins or wild boars. Many occur in stone, such as the Tarasque of Noves (Bouches-duRhône), a seated lion just over $1 \mathrm{~m}$ tall with its front paws resting on two bearded, severed heads and an arm protruding from its sharply toothed mouth. ${ }^{48}$ One image which has been compared on various occasions to the Woodeaton figure is the she-wolf on a second-century pediment from Arlon, Belgium. ${ }^{49}$ However, there are also three examples in bronze: one from Fouqueure (Charente) (FIG. 11b) and two from an excavation at Chartres (Eure-et-Loir). ${ }^{50}$ The Chartres examples are interesting, since one is of a naturalistic dog or wolf very like the examples from Woodeaton and Fouqueure, while the other is larger and more stylised, with a roughly depicted mane around its neck. They were recovered from what appears to be a ritual site of first- and second-century date in which deposits of complete pottery vessels, animal 
and human bones were deposited in wells and pits. ${ }^{51}$ The object protruding from the mouth of the second creature is less obviously a human figure. Similarly, perhaps the Llys Awel dogs represent a development from these man-eating creatures and the body has become a tongue. A further link between the Chartres and Llys Awel figurines is provided by their deposition: the Chartres figurines were ritually deposited in a well, while the Llys Awel dogs were found near the hillfort of Pen-y-Corddyn deposited with other material - such as the Mercury figurine and plaques mentioned above, as well as over 500 coins including at least three fourth-century coin hoards - at a spring. ${ }^{52}$

The two factors common to these images are the large size of the animal in relation to the small human and the limpness of the human body. These have led to the suggestion that the wolf represents a divine image (either a deity itself or a deity in animal form) associated with the underworld. ${ }^{53}$ Dogs are often associated with healing, but it is their link with the gods of the underworld such as Pluto and Serapis that is perhaps more relevant here, while Cerberus was the hound with multiple heads which guarded the gates to Hades. Their association with death and resurrection is also demonstrated by the deposition of dog figurines in clay or bronze in graves and their appearance on funerary monuments. ${ }^{54}$

\begin{tabular}{lc} 
Classical & Total \\
\hline Venus & 29 \\
Bacchic & 24 \\
Genius Paterfamilias & 18 \\
Mars & 47 \\
Vulcan & 10 \\
Provincial & \\
\hline Minerva & 33 \\
Mother Goddess & 11 \\
Mars & 47 \\
Mars? & 47 \\
Mercury & 116 \\
Neptune & 1 \\
Sucellus & 1 \\
Vulcan & 10 \\
Unidentified & -
\end{tabular}

TABLE 1. FIGURE TYPES IN THE SOUTHBROOM HOARD

Total $=$ the number of figurines of that type recorded in Durham 2012 from Roman Britain.

\section{DISCUSSION}

The figurines in the Southbroom hoard consist of examples in both classical and provincial styles, but how does the hoard composition compare with the totality of figurines from Britain? Table 1 lists the figurines of each style. It is immediately apparent that the majority of the figurines are male. However, the three female figurines comprise 21.4 per cent of the group, which is in fact the same proportion of female figurines for the entire British assemblage. ${ }^{55}$ It is interesting that there is no Mercury or Hercules, the two most common male figurine deities in Britain, among the classical figurines, although there is a Venus, the second most common female deity. On the other hand, there is a Mercury and a Minerva among the provincial figurines - the most common male and female deities in Britain. Considering the Southbroom collection as a whole, it would seem to represent a rather idiosyncratic group. Vulcan is not particularly popular in Britain, and yet there are two here, 
one in each style. Neptune and Sucellus represent the only examples of their type in Britain. Mars, with two examples and a possible third, is the most common in the group and it is interesting to note that the depictions are extremes of their type: the classical piece showing the nude Mars with crested helmet, while the provincial Mars is depicted with ram-horned snakes.

The deities making up the Southbroom hoard invite questions regarding the origin of the figurines. Depictions of Sucellus, the hammer-god, are fairly common in stone and bronze in Gaul, but not in Britain. In fact the only other object from Britain definitely associated with Sucellus is a silver finger-ring from York engraved with a dedication to the god, ${ }^{56}$ although a sceptre-binding from Farley Heath (Surrey) is thought to show the god along with a raven, dog and stag. ${ }^{57}$ However, it should be noted that Sucellus is the only Gallo-Roman deity regularly depicted in bronze, and only Epona - a Gaulish fertility deity often depicted riding or accompanied by horses - appears with similar frequency but on stone. ${ }^{58}$ The homogeneity of Sucellus' image as a mature man, with long curly hair, beard, belted short tunic and breeches and carrying his two attributes - the hammer and small pot - is noted by various authors and this image remains largely fixed in the bronze figurines, although it is less conservative on stone depictions. ${ }^{59}$ Stephanie Boucher, in her various discussions of Sucellus figurines, notes that it is more common for figures to have the left arm raised and the right holding the vessel, and that sometimes this stance is reversed, but she does not mention the stance of the Southbroom, Augst and Chalon figures (apart from in her catalogue description of the Chalon figurine). However, she does illustrate a figure holding the pot in his left hand, like the Augst and Chalon figurines, and with his right hand only very slightly raised. ${ }^{60}$

Paul-Marie Duval notes that in his tunic and breeches Sucellus is dressed in clothes suitable to the climate in which he is found, unlike the Mediterranean dress of the classical deities. ${ }^{61}$ Yet Boucher points out that the Gallo-Roman Sucellus conforms to the conventions of the Roman pantheon in his stance and attributes. The pot, like Jupiter's thunderbolt or Mercury's purse, symbolises direct divine power in their relations with the human world, while the hammer, like the sceptre or caduceus, is a symbol of the god's power over his domain. ${ }^{62}$ Sucellus is a god with various guises, as a sky god, god of prosperity, war and the underworld and it is in this last guise that he has been linked to Dispater. ${ }^{63}$ On stone reliefs Sucellus is sometimes depicted together with a dog, an animal which often accompanies Silvanus, with whom Sucellus is also sometimes joined. ${ }^{64}$ Ernest Black associates the ritual deposition of dogs in South-East England with the worship of the god Sucellus in his role as god of the underworld, and thus linking them not to healing cults but to the 'devouring and transforming nature of the god'. ${ }^{65}$

It is not just Sucellus who provides a link with Gallo-Roman beliefs in the Southbroom hoard: the ram-horned snake, raven-topped helmet and carnivorous dog are also found there. The earliest appearance of the ram-horned snake is on the silver Gundestrup cauldron where it is seen on several panels, including leading a band of warriors and being held by a seated Cernunnos. Although the place of origin of the cauldron has been much debated, it has often been argued that some of the symbols, including that of the ram-horned snake, have a Gaulish origin. ${ }^{66}$ The creature also appears in association with Cernunnos on several Gaulish statues from Sommerécourt (Haute Marne), Yzeures-sur-Creuse (Indre-etLoire) and Crêt Chatelard (Loire). ${ }^{67}$ Garrett Olmsted calls the ram-horned snake "the Gaulish mythical animal "par excellence", since it is most common in central and north-east France, but is rarely seen outside that region. ${ }^{68}$ It is also on the Gundestrup cauldron that we find early depictions of bird-topped helmets like that adorning the head of Mars M4. ${ }^{69}$ Finally, there is the carnivorous beast, found predominantly in Gaul but also in Britain, and perhaps serving as the inspiration for the dogs found at Llys Awel and in the Southbroom hoard. 
This wealth of Gaulish inspired images might indicate an origin in that province for the figurines of the Southbroom hoard, but it must be noted that all of these images also occur in Britain, often on sites not far from Southbroom itself. The similarities between the Southbroom, North Bradley, Henley Wood and Motcombe figurines in particular suggest the presence of an artistic tradition based in the south-west of Britain. However, one must always take care when comparing pieces on stylistic grounds, particularly when they are based on simple or stylised features. As Catherine Johns has pointed out, many features such as large eyes and a wedge-shaped nose are characteristic of naïve art more generally. ${ }^{70}$ For instance, one might consider other figures which bear some similarities to the south-western group, in particular two figures of Mars from London and Tiel in the Netherlands. ${ }^{71}$ Both wear a helmet, tunic and cuirass with simply depicted pleats on the skirt and basic modelling of the body. Although, like the south-west group, they fall within the slightly stylised provincial style common to Britain and Gaul, the specific details of the body and clothing do not belong to those characterising the south-west figurines. The fact that this small group is based primarily within a limited geographical area (FIG. 1) does suggest that it represents the work of a limited number of artisans operating within a particular tradition. Foster has suggested that metalsmiths producing high quality goods in Iron Age Britain may well have been itinerant and that they would have produced a group of pieces in a single episode at a site, such as at Gussage All Saints (Dorset). ${ }^{72}$ The large number of unique pieces within the Southbroom hoard might well represent such an episode. The single outlying figure of the Dragonby Mars, which displays a number of the features characterising this group, could be the result of trade or the product of an itinerant metalsmith working within this tradition.

In any discussion of figurines one must consider their portability. As small personal objects, they could be transported easily with their owner, thus their place of deposition need not relate closely to their place of origin. In addition, their small size means that figurines could have been easily held in a hand, and the wear on some figures, in particular that on the Henley Wood Mother Goddess, is seen as evidence for the repeated handling of a muchloved or respected object. ${ }^{73}$ Aldhouse-Green emphasises the link between the image depicted in the figurine and the context and use of the piece, which may have changed with time, location and owner. ${ }^{74}$ However, these factors needn't be limited to small objects that can be transported in a pocket, but also larger pieces such as the Silchester eagle, that also had a long and changing life history and which, like the Henley Wood figurine, may have been deliberately deposited. ${ }^{75}$

Unfortunately, the majority of the pieces under discussion come with little contextual information which might help to determine whether they are linked chronologically as well as spatially. The Henley Wood Mother Goddess was excavated from a fourth-century layer of metalling in the temple precinct; although Henig would assign the piece an earlier date, perhaps in the first century A.D. ${ }^{76}$ The Motcombe boar was found by chance on the site of Duncliffe Hill with a figurine of Fortuna. ${ }^{77}$ Henig offers a date in the second century for the Fortuna, while he believes that the boar is somewhat earlier in date, probably dating towards the end of the Iron Age. ${ }^{78} \mathrm{He}$ also notes that the location, on the spur of a hill with views across a valley and a spring on the lower slopes of the hill, is typical of many Roman temple sites in this area, although there is as yet no evidence for such a structure other than, perhaps, these figurines.

The Southbroom figurines are also without context details, but it is interesting to note that like the Motcombe boar, the figurines considered in detail here were found with figurines of classical, Graeco-Roman style and a coin of Severus Alexander dated to 222-35 A.D. ${ }^{79}$ However, as Henig notes, the presence of the coin does not necessarily date the figurines, which he believes are likely to be earlier. On stylistic grounds Henig dates the North Bradley 
Vulcan before the end of the second century. ${ }^{80}$ Many of the objects from Gaul displaying the same imagery are also dated to the early Roman period and the Gundestrup cauldron slightly earlier, perhaps in the first century B.C. ${ }^{81}$ Thus at the moment the best date one can give for this group is some time in the early Roman period. The Southbroom figurines in particular represent a time when native traditions from the late Iron Age were merging with the ideas introduced by the Romans, in this case to produce a new local style. However, the use of style in both the dating and analysis of Romano-British art is highly debated. ${ }^{82}$ In assigning the figurines under discussion here an early date, Henig is equating the simple and 'Celtic' style with an early date. However, one should perhaps place as much, if not more, emphasis on the themes depicted both in individual objects and groups in which the use of Late Iron Age and Gallo-Roman motifs might signal deliberate choices influenced, in part, by both the various artistic styles to which Romano-British artists would have been exposed and their attitudes towards their Roman conquerors. ${ }^{83}$ As objects associated with ritual and religion, the motifs used on figurines are also important indicators of the adoption of the Graeco-Roman pantheon and practices associated with Roman religion. Here also there has been much debate over the nature of syncretism between Celtic and Roman religion, with some seeing it as a largely benign process in which the similarities between Celtic and Roman traditions allowed change and growth within native religious practice. ${ }^{84}$ Jane Webster in particular has questioned this idea and, while she agrees that Romano-British religion saw an adaptation of introduced religious ideas, she feels that the changes were conducted within the context of an imperial situation in which the native population were involved in a power struggle with the dominant Roman incomers and she uses the term creolisation - the relationship between material hybridity and power inequality - to describe the process. ${ }^{85}$ The fact that the arguments presented by authors such as Aldhouse-Green and Webster are in fact centred on evidence from Gaul indicates not only the scarcity of evidence from Britain, but also serves to highlight the regional nature of Romano-Celtic beliefs. This is the focus of recent work by Martin Goldberg who thinks that the local character of much of the evidence is bypassed in order to create a widespread syncretistic model of Romano-Celtic religion. Instead he prefers to use the term vernacular to indicate the essentially local and non-élite character of native Romano-British beliefs. ${ }^{86}$ The figurines of the Southbroom hoard and the Llys Awel dogs could certainly fit within a regional group in which motifs such as the ram-horned snake, raven and carnivorous beast are being utilised.

The Southbroom hoard stands out from others containing figurines in Britain, not only because of its size (it contains the largest number of figurines), but also its mix of highly classical and idiosyncratic provincial pieces. ${ }^{87}$ Figurines have been found in four other hoards from Willingham Fen (Cambs); Felmingham Hall (Norfolk), Ashwell (Herts.) and Barkway (Herts.) (Table 2). There is no indication of a settlement or temple site in the vicinity of the Southbroom hoard, or the hoards from Willingham Fen, Felmingham Hall and Barkway. The Ashwell hoard, however, was found on a Romano-British settlement that also has substantial evidence for ritual activity. ${ }^{88}$ Although, unlike the Southbroom hoard, the figurines form only a small part of these other hoards, the one factor common to them all is the presence of a mixture of objects associated with both Romano-Celtic and Romano-British religion. The hoard from Willingham Fen includes two horse and rider figurines, a Mars figurine, raven, owl and three masks, while that from Felmingham Hall contains a ceramic vessel in the shape of a bronze cauldron, a Lar figurine, bronze head of a possible Celtic deity, a head of a sun god, a miniature wheel, three masks and two possible raven attachments. ${ }^{89}$ Although the objects from Ashwell are themselves typically Romano-British, the use of a Fortuna figurine and plaques depicting Minerva in veneration of Senuna - who was presumably a local Romano-Celtic deity - links the pieces to those under discussion here. ${ }^{90}$ Finally, from Barkway the Mars figurine and plaques are again more typically Roman in style, but one 
plaque is dedicated to the Romano-Celtic deity Mars Toutatis. ${ }^{91}$ Since the horse and rider which is particularly common in eastern central England - is thought to represent a local version of Mars, ${ }^{92}$ all of these hoards, except for that from Ashwell, have associations with Mars (including figurines of the deity himself) and/or birds and animals with chthonic attributes - in particular the raven and the dog. It is only at Llys Awel that the dogs may take on a healing role rather than a chthonic one.

\begin{tabular}{|c|c|c|c|}
\hline Hoard & Figurines & Other metal objects & $\begin{array}{l}\text { Other non-metal } \\
\text { objects }\end{array}$ \\
\hline Willingham Fen & $\begin{array}{l}\text { Mars } \\
\text { Two horse and riders } \\
\text { Raven }\end{array}$ & $\begin{array}{l}\text { Three masks } \\
\text { Sceptre } \\
\text { Owl attachment } \\
\text { Ox head attachment } \\
\text { Lion Head attachment } \\
\text { Horse bit }\end{array}$ & $\begin{array}{l}\text { Wooden box } \\
2 \text { jet rings } \\
1 \text { amber bead } \\
3 \text { glass beads }\end{array}$ \\
\hline Felmingham Hall & Lar Compitalis & $\begin{array}{l}\text { Head of a ?Celtic deity } \\
\text { Head of Minerva } \\
\text { Head of a sun god } \\
\text { Miniature wheel } \\
\text { Three masks } \\
2 \text { ?raven attachments } \\
\text { Rattle } \\
\text { Sceptre fragments } \\
\text { Coin dating to AD } 260\end{array}$ & Ceramic vessel \\
\hline Ashwell & $\begin{array}{l}\text { Senuna-Fortuna } \\
\text { Two arm fragments }\end{array}$ & $\begin{array}{l}13 \text { silver plaques depicting Minerva } \\
7 \text { gold plaques depicting Minerva } \\
\text { Jewellery }\end{array}$ & \\
\hline Barkway & Mars & $\begin{array}{l}4 \text { plaques depicting Mars } \\
2 \text { plaques depicting Vulcan } \\
1 \text { plaque with a dedication to Mars } \\
\text { Toutatis } \\
\text { Handle, possibly from a rattle }\end{array}$ & \\
\hline
\end{tabular}

\section{TABLE 2. FINDS FROM HOARDS}

The Southbroom hoard is also unusual in comparison with other hoards from elsewhere in Europe. Kaufmann-Heinimann surveyed hoards containing figurines and there are numerous examples containing provincially produced figurines, but only a few contain figurines of deities who do not belong to the Graeco-Roman pantheon and these are Epona, Rosmerta (a Gaulish deity often associated with Mercury), Naria (a local goddess from western Switzerland, probably associated with fertility) and Artio (a local goddess of agriculture and the forest from the Rhine-Moselle area who is associated with the bear). ${ }^{93}$ Like the Southbroom hoard, the composition of the hoards containing these regional deities is slightly unusual. Epona and Rosmerta were found together in a hoard from Champoulet (Loiret), which also included an Apollo, a less common deity in bronze, and a bull. At Reims (Marne) Epona was found with Aesculapius, who is rarely depicted in bronze, and an unusual figurine group consisting of Venus accompanied by two miniature figurines of Cupid and Priapus. Finally Naria and Artio were found together with a Jupiter, Juno, Minerva and Lar at Muri, Switzerland. Thus these Continental groups also manifest a rather unusual combination of Graeco-Roman deities in association with regional deities, but stylistically all of the figurines follow a classical form in their depiction, rather than using the individual style and attributes seen in the Southbroom figurines. Only a hoard from Neuvy-en-Sullias (Loiret) 
departs from this norm and contains a group of highly individual figurines in combination with others in a classical style. ${ }^{94}$ This hoard was found during quarrying in a pit lined with brick. The figurines in classical style include Mars and Aesculapius and a carriage fitting with a figurine of a child Hercules under an arch of vines. There are also animal figurines two bulls, two boars, a stag and a horse - as well as three saucepans and three votive leaves. However, the figurines of particular interest here are the five men and four women depicted in a unique style. Most are naked, with long torsos, large hips, short legs and tiny feet in comparison to their overly large hands. They appear to be dancing or, with their waving arms and tilted heads, perhaps in a state of religious fervour. The combination of the poses and anatomical oddness give the pieces an effective otherworldly quality. If the large figure clothed in a long-sleeved tunic, with his arms held out in front of him were a priest, then this would leave four dancing couples in the group. ${ }^{95}$ Thus this hoard compares well with the Southbroom group in terms of its use of both classical and native pieces. The Gallo-Roman deities in these Continental hoards include both those with an international reach (Epona and Rosmerta) and those with only a local range (Naria and Artio). Similarly, the Sucellus from Southbroom shows allegiance to a well-known Gallo-Roman deity, while perhaps the putative Mars M2 and M4 could represent a local deity or deities. In addition, the local deities in the Continental hoards show stylistic uniformity and those in the Neuvy-en-Sullias group are almost certainly the product of a single workshop, while the Naria and Artio figurines from Muri also show stylistic details which suggest they are the product of a single workshop. $^{96}$

To conclude, the figurines of the Southbroom group include both Roman and Romano-Celtic deities, as well as a Romano-British style which combines the use of late Iron Age trends, such as stylisation and the torc, with the Roman tendency towards naturalism and attributes such as the patera. The variety of deity types, but consistency of style, exhibited by the south-west group indicates a distribution which is limited to production by one or two artisans or workshops. As such, production by a single bronzesmith would necessitate a narrow chronological range for the pieces, and the Iron Age influences would suggest a date earlier in the Roman period. Finally, the fact that the figurines of this south-west group and the carnivorous dogs are often found in association with typically classical pieces, suggests a certain inclusivity in their use, and one in which worshippers took on a variety of religious influences, both local and imported. 
Appendix. Details of the figurines discussed in the text

\begin{tabular}{|c|c|c|c|c|c|c|}
\hline Identification & Site & $\begin{array}{l}\text { Durham } \\
2012 \text { no. }\end{array}$ & $\begin{array}{l}\text { Musgrave } \\
1719 \text { no. }\end{array}$ & $\begin{array}{l}\text { Height } \\
(\mathrm{mm})\end{array}$ & $\begin{array}{l}\text { Length } \\
(\mathrm{mm})\end{array}$ & References \\
\hline Venus & Southbroom & 375 & 1 & 158 & & Cunnington 1854; Boon 1973 \\
\hline Mars & Southbroom & 373 & 2 & 125 & & $\begin{array}{l}\text { Cunnington 1854; Boon 1973; Green } \\
1976,191\end{array}$ \\
\hline Neptune & Southbroom & 374 & 3 & 104 & & $\begin{array}{l}\text { Cunnington 1854; Boon 1973; Green } \\
1976,191\end{array}$ \\
\hline Mars & Southbroom & 371 & 4 & 107 & & $\begin{array}{l}\text { Cunnington 1854; Boon 1973; Green } \\
\text { 1976, } 191\end{array}$ \\
\hline Vulcan & Southbroom & 376 & 5 & 88 & & Cunnington 1854; Boon 1973 \\
\hline Mercury & Southbroom & 334 & 6 & 108 & & $\begin{array}{l}\text { Cunnington 1854; Toynbee 1964, 72; } \\
\text { Boon 1973; Green 1976, 191, pl. IIIh; } \\
\text { Lindgren 1980, 46-7 }\end{array}$ \\
\hline $\begin{array}{l}\text { Mother } \\
\text { Goddess }\end{array}$ & Southbroom & 337 & 7 & 96 & & $\begin{array}{l}\text { Cunnington 1854; Boon 1973; Green } \\
\text { 1976, 191; Lindgren 1980, } 79\end{array}$ \\
\hline Minerva & Southbroom & 340 & 8 & 81 & & $\begin{array}{l}\text { Cunnington 1854; Toynbee 1964, 82; } \\
\text { Boon 1973; Lindgren 1980, 91-2 }\end{array}$ \\
\hline $\begin{array}{l}\text { Genius } \\
\text { Paterfamilias }\end{array}$ & Southbroom & 383 & 9 & 82 & & $\begin{array}{l}\text { Cunnington 1854; Boon 1973; Alcock } \\
\text { 1986, } 126\end{array}$ \\
\hline Mars & Southbroom & 377 & 10 & 82 & & Cunninton 1854; Boon 1973 \\
\hline Sucellus & Southbroom & 372 & 11 & 96 & & $\begin{array}{l}\text { Cunnington 1854; Boon 1973; Green } \\
1976,191\end{array}$ \\
\hline Vulcan & Southbroom & 344 & 13 & 100 & & $\begin{array}{l}\text { Cunnington 1854; Boon 1973; Green } \\
\text { 1976, 191; Lindgren 1980, } 109\end{array}$ \\
\hline Unidentified & Southbroom & 379 & 14 & 50 & & Cunnington 1854; Boon 1973 \\
\hline $\begin{array}{l}\text { Three-horned } \\
\text { bull }\end{array}$ & Southbroom & 378 & 15 & & 100 & Cunnington 1854; Boon 1973 \\
\hline Dog monster & Southbroom & 380 & 16 & & 88 & Cunnington 1854; Boon 1973 \\
\hline Horse & Southbroom & 381 & 17 & & 82 & Cunnington 1854; Boon 1973 \\
\hline Bacchus & Southbroom & 382 & 18 & 75 & & Cunnington 1854; Boon 1973 \\
\hline Vulcan & North Bradley & 829 & - & 106 & & Henig 1991 \\
\hline Mars & Dragonby & 13 & - & 98 & & $\begin{array}{l}\text { Green 1976, 162, pl. Ia; Alcock 1989; } \\
\text { Alcock 1996, 264-7, fig 11.15, no } 2\end{array}$ \\
\hline $\begin{array}{l}\text { Mother } \\
\text { Goddess }\end{array}$ & $\begin{array}{l}\text { Henley Wood } \\
\text { Temple }\end{array}$ & 5 & - & 75 & & $\begin{array}{l}\text { Wilson 1970, 296, pl XXXV; Pitts } \\
\text { 1979, no. 135; Henig 1996, 131-3, no } \\
\text { 161, fig. } 110 \text {, pl. 30-3 }\end{array}$ \\
\hline Boar & Motcombe & 775 & - & 20 & 39 & Henig and Keen 1985 \\
\hline Rider & Ashdown & 571 & - & 64 & & Toynbee 1964, 119; Green 1976, 192 \\
\hline Dog monster & Llys Awel & 1176 & - & 53 & & \\
\hline Dog monster & Llys Awel & 1177 & - & 58 & & \\
\hline Dog & Llys Awel & 1178 & - & 45 & 53 & \\
\hline Dog monster & Woodeaton & 20 & - & 68 & & $\begin{array}{l}\text { Reinach 1904; Alcock 1963, 119, pl. } \\
\text { XIX; Boucher 1973, no. 269; Henig } \\
\text { and Munby 1973, pl. XXX; Green } \\
\text { 1976, 177; Pitts 1979, no. 144, pl. 23; } \\
\text { Bagnall Smith 1995, } 181\end{array}$ \\
\hline
\end{tabular}

\section{BIBLIOGRAPHY}

Alcock, J.P. 1963: 'Three bronze figurines in the British Museum', Antiquaries Journal 43, $118-23$

Alcock, J.P. 1986: 'The concept of Genius in Roman Britain', in Henig and King 1986, 113 33 
Alcock, J.P. 1989: 'Two bronze figurines from Dragonby South Humberside', Lincolnshire History and Archaeology 24, 57-9

Alcock, J.P. 1996: 'Figurines of Mars from Dragonby', in J. May (ed.), Dragonby: Report on Excavations at an Iron Age and Romano-British Settlement in North Lincolnshire, Oxford, 264-7

Aldhouse-Green, M. 2004: An Archaeology of Images. Iconology and Cosmology in Iron Age and Roman Europe, London/New York

Andrews, P. 2008: 'Springhead, Kent - old temples and new discoveries', in Rudling 2008, 45-62

Armand-Calliat, L. 1937: Le Chalonnais gallo-romain, Chalon-sur-Sâone

Bagnall Smith, J. 1995: 'Interim report on the votive material from Romano-Celtic temple sites in Oxfordshire', Oxoniensia 60, 177-203

Black, E. 1985: 'A note on the Farley Heath sceptre-binding', Surrey Archaeological Collections 76, 140-2

Black, E. 2008: 'Pagan religion in rural south-east Britain: contexts, deities and belief', in Rudling 2008, 1-25

Boon, G.C. 1973: 'Genius and lar in Celtic Britain', Jahrbuch des Romisch-Germanischen Zentralmuseums Mainz 20, 265-9

Boon, G.C. 1983: 'A priest's rattle of the third century A.D. from the Felmingham, Norfolk, find', Antiquaries Journal 63, 363-4

Boucher, S. 1971: Vienne. Bronzes antiques, Inventaire des collections publiques françaises 17, Paris

Boucher, S. 1976: Recherches sur les bronzes figurés de Gaule pré-romaine et romaine, Rome

Boucher, S. 1983: Les bronzes figurés antiques, Lyon

Boucher, S. 1988: 'L'image et les fonctions du dieu Sucellus', in Le monde des images en Gaule et dans les provinces voisines, Caesarodunum 23, Paris, 76-85

Braemar, F. 1995: 'Problèmes de chronologie, bilan et perspectives', in Mols et al. 1995, 241-51

Chauvet, G. 1901: 'Statues, statuettes et figures antiques de la Charente', Revue Archéologique 1901, 272-81

Crummy, N. 2010: 'Bears and coins: the iconography of protection in late Roman infant burials', Britannia 41, 37-93

Cunliffe, B.W., and Fulford, M.G. 1982: Corpus Signorum Imperii Romani, Great Britain, I, 2, Bath and the Rest of Wessex, Oxford

Cunnington, W. 1854: 'The penates found at Devizes, in 1714', Wiltshire Archaeological Magazine 1, 214

de Kisch, Y. 1978: 'Informations archéologiques. Circonscription du Centre', Gallia 36, 26193

de Kisch, Y. 1980: 'Informations archéologiques. Circonscription du Centre', Gallia 38, 31247 
Deonna, W. 1915/16: Catalogue des bronzes figures antiques, Geneva

Deyts, S. 1992: Images des dieux de la Gaule, Paris

Draper, J. 1985: Excavations by Mr H.P. Cooper on the Roman Site at Hill Farm, Gestingthorpe, Essex, East Anglian Archaeology 25, Chelmsford

Durham, E. 2012: 'Depicting the gods: metal figurines in Roman Britain', Internet Archaeology 31, http://intarch.ac.uk/journal/issue31/durham_index.html

Durham, E. forthcoming: 'Symbols of power: the Silchester bronze eagle and eagles in Roman Britain', Archaeological Journal

Duval, A., and Heude, D. (eds) 1983: L'Art celtique en Gaule, Direction des Musées de France, Paris

Duval, P.-M. 1976: Les dieux de la Gaule, Paris

Eckardt, H. 2002: Illuminating Roman Britain, Monographies Instrumentum 23, Montagnac

Eckardt, H. 2005: 'The social distribution of Roman artefacts: the case of nail cleaners and brooches in Britain', Journal of Roman Archaeology 18, 139-60

Eckardt, H. 2006: 'The character, chronology, and use of the late Roman pits: the Silchester finds assemblage', in M.G. Fulford, A. Clarke and H. Eckardt (eds), Life and Labour in Late Roman Silchester. Excavations in Insula IX since 1997, Britannia Monograph 22, London, 221-45

Fleischer, R. 1967: Die römischen Bronzen aus Österreich, Mainz

Foster, J. 1995: 'Metalworking in the British Iron Age: the evidence from Weelsby Avenue, Grimsby', in B. Raftery (ed.), Sites and Sights of the Iron Age. Essays on Fieldwork and Museum Research Presented to Ian Matheson Stead, Oxbow Monograph 56, Oxford, 4960

Frere, S.S. 1970: 'Mould for bronze statuette from Gestingthorpe, Essex', Britannia 1, 266-7

Galestin, M.C. 1995: 'Dating of Roman bronze statuettes: fixed types and changing styles', in Mols et al. 1995, 253-60

Gilbert, H.M. 1978: 'The Felmingham Hall hoard, Norfolk', Bulletin of the Board of Celtic Studies 28.1, 159-87

Goldberg, D.M. 2009: 'The dichotomy in Romano-Celtic syncretism: some preliminary thoughts on vernacular religion', in M. Driessen, S. Heeren, S. Hendricks, F. Kimmers and R. Visser (eds), TRAC 2008. Proceedings of the Eighteenth Theoretical Roman Archaeology Conference, Oxford, 187-202

Goodchild, R.G. 1947: 'The Farley Heath sceptre', Antiquaries Journal 27, 83-8

Green, M.J. 1976: A Corpus of Religious Material from the Civilian Areas of Roman Britain, BAR British Series 24, Oxford

Green, M.J. 1986: The Gods of the Celts, Gloucester

Green, M.J. 1989: Symbol and Image in Celtic Religious Art, London

Green, M.J. 1998: 'God in man's image: thoughts on the genesis and affiliations of some Romano-British cult imagery', Britannia 29, 17-30

Henig, M. 1984: Religion in Roman Britain, London 
Henig, M. 1991: 'A bronze Vulcan from North Bradley', Wiltshire Archaeological Magazine $84,120-2$

Henig, M. 1993: Corpus Signorum Imperii Romani, Great Britain, I, 7, Roman Sculpture from the Cotswold Region with Devon and Cornwall, Oxford

Henig, M. 1995: The Art of Roman Britain, London

Henig, M. 1996: 'The bronze figurine', in Watts and Leach 1996, 31-3

Henig, M., and Keen, L. 1985: 'Figurines from Duncliffe Hill, Motcombe, Dorset', Proceedings of the Dorset Natural History and Archaeological Society 106, 147-8

Henig, M., and King, A. (eds) 1986: Pagan Gods and Shrines of the Roman Empire, Oxford University Committee for Archaeology Monograph 8, Oxford

Henig, M., and Munby, J. 1973: 'Three bronze figurines', Oxoniensia 38, 386-7

Henig, M., and Rudkin, D. 2009: 'An Iron-Age-style statue of a fertility goddess from Fishbourne', Sussex Archaeological Collections 147, 213-14

Hunter, F. 2007: 'Artefacts, regions, and identities in the northern British Iron Age', in C. Haselgrove and T. Moore (eds), The Later Iron Age in Britain and Beyond, Oxford, 28696

Jackson, R., and Burleigh, G. 2007: 'The Senuna treasure and shrine at Ashwell (Herts.)', in R. Haeussler and A.C. King (eds), Continuity and Innovation in Religion in the Roman West Vol. 1, Journal of Roman Archaeology Supplementary Series 67, Portsmouth, Rhode Island, 37-54

Jenkins, F. 1957: 'The role of the dog in Romano-Gaulish religion', Latomus 16, 60-76

Johns, C. 2003: 'Romano-British sculpture: intention and execution', in P. Noelke (ed.), Romanisation und Resistenz in Plastik, Architektur und Inschriften der Provinzen des Imperium Romanum, Mainz, 27-38

Kaufmann-Heinimann, A. 1977: Die römischen Bronzen der Schweiz. I Augst und das Gebiet der Colonia Augusta Raurica, Mainz

Kaufmann-Heinimann, A. 1998: Götter und Lararien aus Augusta Raurica, Forschungen in Augst 26, Augst

Kaul, F. 1991: 'The Gundestrup cauldron - Thracian, Celtic or both?', in F. Kaul, I. Marazov, J. Best and N. de Vries, Thracian Tales on the Gundestrup Cauldron, Amsterdam, 7-42

King, A. 1990: 'The emergence of Romano-Celtic religion', in T.F.C. Blagg and M. Millett (eds), The Early Roman Empire in the West, Oxford, 220-41

Lebel, P. 1961: Catalogue des collections archéologiques de Besançon, V, Les bronzes figurés, Paris

Lebel, P., and Boucher, S. 1975: Bronzes figurés antiques (grecs, étrusques et romains), Paris

Leibundgut, A. 1980: Die römischen Bronzen der Schweiz, III Westschweiz, Bern und Wallis, Mainz

Lindgren, C. 1980: Classical Art Forms and Celtic Mutations. Figural Art in Roman Britain, Park Ridge, New Jersey

Manley, J.F. 1982: 'Finds from Llys Awel, Abergele', Archaeology in Clwyd 5, 6-7 
Millett, M. 1995: 'Re-thinking religion in Romanization', in J. Metzler, M. Millett, N. Roymans and J. Slofstra (eds), Integration in the Early Roman West. The Role of Culture and Ideology, Luxembourg, 93-100

Mitten, D.G., and Doeringer, S.F. 1968: Master Bronzes from the Classical World, Mainz

Mols, S.T.A.M., Gerhartl-Witteveen, A.M., Kars, H., Koster, A., Peters, W.J.T., and Willems, W.J.H. (eds), 1995: Acta of the 12th International Congress on Ancient Bronzes, Nijmegen 1992, Nederlandse Archeologische Rapporten 18, Nijmegen

Musgrave, W. 1719: Antiquitates Britanno-Belgicae, praecipue Romanae, figuris illustratae. Volume I De Belgio Britannico, Exeter

Olmsted, G.S. 1979: The Gundestrup Cauldron, Collection Latomus 162, Brussels

Phillips, E.J. 1977: 'The Classical tradition in the popular sculpture of Roman Britain', in J. Munby and M. Henig (eds), Roman Life and Art in Britain. A Celebration in Honour of the Eightieth Birthday of Jocelyn Toynbee, BAR British Series 41, Oxford, 35-49

Pitts, L.F. 1979: Roman Bronze Figurines from the Civitates of the Catuvellauni and Trinovantes, BAR British Series 60, Oxford

Reinach, S. 1904: 'Les carnassiers androphages dans l'art Gallo-Romain', Revue Celtique 25, 208-24

Renard, M. 1949: 'La louve androphage d'Arlon', Latomus 8, 255-62

RIB II.3: S.S. Frere and R.S.O. Tomlin (eds), The Roman Inscriptions of Britian, II. Instrumentum Domesticum: Fasc. 3, Brooches, Rings, Gems, Bracelets, Helmets, Shields, Weapons, Iron Tools, Baldric Fittings, Votives in Gold, Silver and Bronze, Lead Pipes, Roundels, Sheets and Other Lead Objects, Stone Roundels, Pottery and Bone Roundels, Other Objects of Bone (1991)

Ross, A. 1992: Pagan Celtic Britain (rev. edn.), London

Rostovtseff, M. 1923: 'Commodus-Hercules in Britain', Journal of Roman Studies 13, 91105

Rudling, D. (ed.) 2008: Rural Landscapes of Roman South-East Britain, Great Dunham/Oxford

Serjeantson, D., and Morris, J. 2011: 'Ravens and crows in Iron Age and Roman Britain', Oxford Journal of Archaeology 30.1, 85-107

Stukeley, W. 1724: Itinerarium Curiosum, London

Thevenot, É. 1968: Divinités et sanctuaires de la Gaule, Paris

Toynbee, J.M.C. 1964: Art in Britain under the Romans, Oxford

Toynbee, J.M.C. 1973: Animals in Roman Life and Art, London

Wait, G.A. 1985: Ritual and Religion in Iron Age Britain, BAR British Series 149, Oxford

Walters, H.B. 1914: Catalogue of Greek and Roman Lamps in the British Museum, London

Watts, L., and Leach, P. 1996: Henley Wood, Temples and Cemetery. Excavations 1962-69 by the Late Ernest Greenfield and Others, Council for British Archaeology Research Report 99, York 
Webster, G. 1986: 'What Britons required from the gods as seen through the pairing of Roman and Celtic deities and the character of votive offerings', in Henig and King 1986, $57-64$

Webster, J. 2001: 'Creolizing the Roman provinces', American Journal of Archaeology $105.2,209-25$

Webster, J. 2003: 'Art as resistance and negotiation', in S. Scott and J. Webster, Roman Imperialism and Provincial Art, Cambridge, 24-51

Wilson, D.R. 1970: 'Roman Britain in 1969', Britannia 1, 269-305

Zadoks-Josephus Jitta, A.N. 1984: 'Roman bronze statuettes: another approach to dating', in F. Jeno and F. Gyula (eds), Bronzes Romains figurés et appliqués et leurs problèmes techniques. Actes du VIIe Colloque International sur les Bronzes Antiques, Székesfehérvár, 9-11

Zadoks-Josephus Jitta, A.N., Peters, W.J.T., and van Es, W.A. 1969: Roman Bronze Statuettes from the Netherlands. Vol. 2. Statuettes found South of the Limes, Groningen

Zirra, V. 1991: 'The cemetery of Çiumeşti and the chieftain's tomb', in S. Moscati, O.H. Frey, V. Kruta, B. Raftery and M. Szabó (eds.), The Celts, London, 382-3

1 e.g. Toynbee 1964. Pitts (1979) was unusual in suggesting that many more figurines were produced in Britain than had previously been thought and Henig in particular has long been a proponent of British figurine production.

2 Frere 1970; Draper 1985, 11.

3 For Iron Age Britain, see Wait 1985, 150; for Roman Britain, see, for example, Eckardt 2006; Andrews 2008; Black 2008.

4 Cunnington 1854, 214. British Museum accn nos 1811,0309.1-8. Since there are several examples of Vulcan and Mars figurines in the hoard the figurines are referenced in this paper using their name and number as published in the Musgrave illustrations in figs 2 and 3, e.g. Vulcan M5 or M13. Details and references for the figurines can be found in the Appendix, with further details available in the database attached to Durham 2012.

5 Stukeley 1724, 137; Boon 1973, 267; Durham 2012, section 1.1.

6 Colchester: Eckardt 2002, 378. Other examples: Walters 1914, 6, no. 26 from Crete and 62, no. 430 from Alexandria; Mitten and Doeringer 1968, 298, no. 296 possibly from Alexandria.

7 Boucher 1976, 171; Green 1989, 180; Deyts 1992, 30; Durham 2012, table 5.

8 Boon 1973, 267. 
9 e.g. Minerva: Durham 2012, no. 329 from Bruton (Somerset); Fleischer 1967, 42, Taf. 21, no. 24 from Mauer an der Url, Austria. Vulcan: Durham 2012, no. 194 from Carley Hill Quarry (Northumbd) and no. 829 from North Bradley (Wilts.); Kaufmann-Heinimann 1977, 48, Taf. 44, no. 43 from Augst.

10 Durham 2012, no. 5 from Henley Wood Temple (Somerset) and no. 157 from the Gower Peninsula (Swansea). A small figurine from Welton le Marsh (North Lincs.) has one arm across her stomach and the other raised (North Lincolnshire Museum, Scunthorpe accn no. NOLMS: 2004.097).

11 Henig and Rudkin 2009.

12 Boon 1973, 268, no. 11; Green 1976, 191.

13 Kaufmann-Heinimann 1977, 21, no. 6, Taf. 5; Boucher 1983, 88, no. 63. An almost identical figure to that from Augst was also found at Besançon, France (Lebel 1961, 18, no. 5, pl. VIII). For an example of Sucellus still holding his pot, see Kauffmann-Heinimann 1977, Taf. 5, no. 5.

14 Boon 1973, 267, no. 3; Cunnington 1854, 214.

15 e.g. Boucher 1971, 36, no. 4.

16 Boon 1973, 267, no. 4; Ross 1992, 186; Green 1986, 193.

17 Boon 1973, 267, no. 2.

18 Durham 2012, no. 24 from London, no. 29 from Bury St Edmunds (Suffolk) and no. 525 from Wycomb (Glos.).

19 Kaufmann-Heinimann 1977, Taf. 5, no. 6.

20 Boucher 1983, 88, no. 63.

${ }^{21}$ Zirra 1991, 382-3.

22 Thevenot 1968, 67-8; Olmsted 1979, 24, pl. 3E.

23 Ross 1992, 239; Toynbee 1964, 154; Henig 1993, 18-19, nos 48 and 50, pl. 15.

${ }^{24}$ Ross 1992, 243; Henig 1993, 33, no. 98, pl. 26.

25 Serjeantson and Morris 2011.

26 Phillips 1977, 43; Henig 1995, 99.

${ }^{27}$ Henig and Rudkin 2009, fig. 1.

28 e.g. Lebel and Boucher 1975, 65, no. 99 from Maligny (Côte-d'Or); Kaufmann-Heinimann 1977, Taf. 5, nos 5 and 6 from Augst; Boucher 1983, 88, no. 63 from Chalon.

29 Boon 1973, 268. 
30 Durham 2012, no. 35 from London and no. 796 from the villa at Gurnard Bay (Isle of Wight).

31 Durham 2012, with purse hanging: no. 327 from Bruton (Somerset); with purse on palm: no. 1061 from London and no. 1121 from Crownthorpe (Norfolk).

32 Deonna 1915/16, 17, no. 28.

33 Henig 1984, 66; Boon 1983.

34 Green 1986, 192.

35 Green 1986, 192-4; Henig 1993, 32, no. 93, pls 26 and 57 and no.169, pl. 41.

36 Thevenot 1968, 67-8.

37 Henig 1991, 120. Wiltshire Heritage Museum, Devizes accn no. DZSWS: 1989.221.

38 Henig 1991, 122; Durham 2012, Mars 13. North Lincolnshire Museum Service accn no. SCUNM: 1971.067.

39 Henig 1996, 131. North Somerset Museum accn no. 1986/5441, BZ66.

40 Henig and Keen 1985, 106. Dorset County Museum accn no. 1990.66.1.

41 Durham 2012, no. 55 from St Albans and no. 284 from Richborough.

42 British Museum accn no. 1881,0325.1.

${ }^{43}$ Cunliffe and Fulford 1982, 32-3, no. 116, pl. 31. The relief shows three figures, the central one wears the torc. To her left is a nude male, possibly Mercury or Cupid, and to her right another draped female.

44 Boon 1973, 268, no. 16.

45 Musgrave 1719, table IX.

46 Durham 2012, nos 1176 and 1177. National Museum of Wales accn nos 81.35H/3 and /4.

47 Alcock 1963, 121. British Museum accn no. 1883,0802.12.

48 Reinach 1904, 218-19; Duval and Heude 1983, 138, no. 162.

49 Reinach 1904, 209; Renard 1949; Jenkins 1957, 61; Alcock 1963, 121.

50 Chauvet 1901, fig. 10; de Kisch 1980, fig. 7.

51 de Kisch 1978, 267-8.

52 Manley 1982, 6.

53 Renard 1949, 260; Alcock 1963, 122. 
54 Toynbee 1973, 123.

55 See Durham 2012, table 3. The proportion cited here is for the assemblage of all identified deities recorded in table 3 , i.e. it does not include fragments or human figures.

56 RIB II.3, 2422.21, dedication reads Deo Svcelo.

57 Goodchild 1947; Black 1985.

58 Boucher 1976, 164; 1988, 77; Green 1989, 75.

59 Boucher 1976, 165; 1988, 77; Duval 1976, 63; Green 1989, 75-6; Deyts 1992, 85.

60 Boucher 1976, 164-70; 1983, 88; 1988, 78, fig. 4.

61 Duval 1976, 63.

62 Boucher 1976, 168.

63 Boucher 1976, 164; Duval 1976, 63. Caesar wrote that the Gauls believed they were descended from Dispater (Gallic War 6.18), thus providing another important role for Sucellus.

64 Duval 1976, 63; Deyts 1992, 87, 90.

65 Black 2008, 5.

66 Kaul 1991.

${ }^{67}$ Green 1986, 192; Deyts 1992, 43-4.

68 Olmsted 1979, 92-3.

69 Olmsted 1979, 24.

70 Johns 2003, 36.

71 Durham 2012, Mars 24; Zadoks-Josephus Jitta et al. 1969, no. 33.

72 Foster 1995, 58.

73 Henig 1996, 131.

74 Aldhouse-Green 2004, 16-17.

75 Durham forthcoming.

76 Watts and Leach 1996, 33; Henig 1996, 131.

77 Fortuna no. 776 in Durham 2012.

78 Henig and Keen 1985, 147-8.

79 Boon 1973, 266. 
${ }^{80}$ Henig 1991, 122.

81 Kaul 1991, 9.

82 For discussions of stylistic dating of figurines, see Braemar 1995; Galestin 1995; Zadoks-Josephus Jitta 1984.

83 e.g. Hunter 2007; Webster 2003.

${ }^{84}$ e.g. Green 1998; King 1990; Millett 1995; Webster 1986.

85 Webster 2001, 220-2.

86 Goldberg 2009.

87 Durham 2012, section 4.3.

88 Jackson and Burleigh 2007, 49-52; Durham 2012, section 4.3.

89 Rostovtseff 1923. Cambridge University Museum of Archaeology and Anthropology accn nos 1918.160.1-15 and Z15186-9; Gilbert 1978. British Museum accn nos 1926,0610.1-4, 7-9, 11$13,16,32$.

90 Jackson and Burleigh 2007. British Museum accn nos 2003,0901.1-26.

91 Toynbee 1964, 66, 328-9. British Museum accn nos 1817,0308.1-9.

92 Henig 1995, 51; Eckardt 2005.

93 Kaufmann-Heinimann 1998, 245 GF 23 from Champoulet (Loiret); 261 GF41 from Reims (Marne); 283 GF80 from Muri, Switzerland; Crummy 2010, 57.

94 Kaufmann-Heinimann 1998, 257-8 GF38.

95 Boucher 1976, 41-2.

96 Leibundgut 1980, 66. 